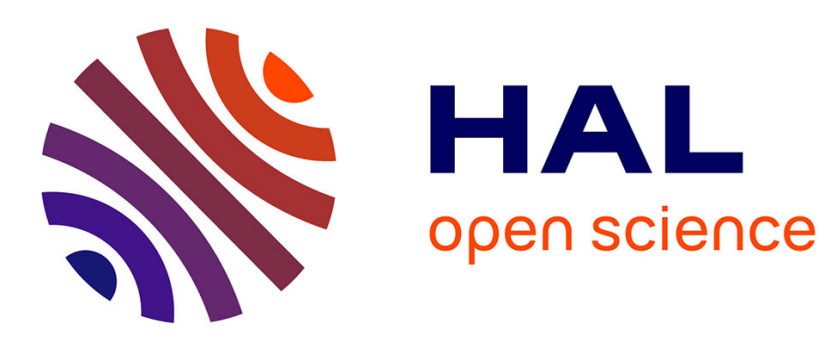

\title{
Pastoral neolithic settlement at Luxmanda, Tanzania
} Katherine Grillo, Mary Prendergast, Daniel A. Contreras, Tom Fitton, Agness Gidna, Steven Goldstein, Matthew Knisley, Michelle Langley, Audax Mabulla

\section{To cite this version:}

Katherine Grillo, Mary Prendergast, Daniel A. Contreras, Tom Fitton, Agness Gidna, et al.. Pastoral neolithic settlement at Luxmanda, Tanzania. Journal of Field Archaeology, 2018, 43 (2), pp.102 - 120. 10.1080/00934690.2018.1431476 . hal-01783062

\section{HAL Id: hal-01783062 https://hal.science/hal-01783062}

Submitted on 28 Mar 2019

HAL is a multi-disciplinary open access archive for the deposit and dissemination of scientific research documents, whether they are published or not. The documents may come from teaching and research institutions in France or abroad, or from public or private research centers.
L'archive ouverte pluridisciplinaire HAL, est destinée au dépôt et à la diffusion de documents scientifiques de niveau recherche, publiés ou non, émanant des établissements d'enseignement et de recherche français ou étrangers, des laboratoires publics ou privés. 


\section{Pastoral Neolithic Settlement at Luxmanda, Tanzania}

Katherine M. Grillo, Mary E. Prendergast, Daniel A. Contreras, Tom Fitton, Agness O. Gidna, Steven T. Goldstein, Matthew C. Knisley, Michelle C. Langley \& Audax Z. P. Mabulla 


\title{
Pastoral Neolithic Settlement at Luxmanda, Tanzania
}

\author{
Katherine M. Grillo ${ }^{a *}$, Mary E. Prendergast ${ }^{b *}$, Daniel A. Contreras ${ }^{c, d}$, Tom Fitton ${ }^{e}$, Agness O. Gidna ${ }^{f}$, Steven \\ T. Goldstein ${ }^{g}$, Matthew C. Knisley ${ }^{h}$, Michelle C. Langley ${ }^{i}$ and Audax Z. P. Mabulla ${ }^{f}$
}

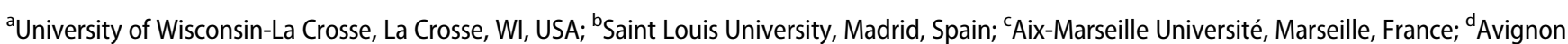
Université, Avignon, France; ${ }^{e}$ University of York, York, UK; ${ }^{\mathrm{f}}$ National Museum of Tanzania, Dar es Salaam, Tanzania; ${ }^{9}$ Max Planck Institute for the

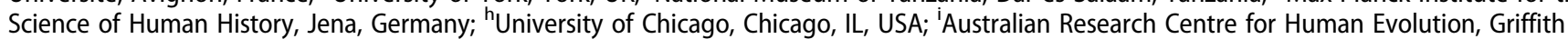
University, Nathan, Queensland, Australia

\begin{abstract}
The later Holocene spread of pastoralism throughout eastern Africa profoundly changed socioeconomic and natural landscapes. During the Pastoral Neolithic (ca. 5000-1200 B.P.), herders spread through southern Kenya and northern Tanzania-areas previously occupied only by huntergatherers-eventually developing the specialized forms of pastoralism that remain vital in this region today. Research on ancient pastoralism has been primarily restricted to rockshelters and special purpose sites. This paper presents results of surveys and excavations at Luxmanda, an openair habitation site located farther south in Tanzania, and occupied many centuries earlier, than previously expected based upon prior models for the spread of herding. Technological and subsistence patterns demonstrate ties to northerly sites, suggesting that Luxmanda formed part of a network of early herders. The site is thus unlikely to stand alone, and further surveys are recommended to better understand the spread of herding into the region, and ultimately to southern Africa.
\end{abstract}

\section{Introduction}

Pastoralism, a way of life centered around the herding and management of livestock, has been a mainstay of eastern African economies for more than three thousand years. Cattle pastoralism is well suited to semi-arid environments with unpredictable shifts in water and pasture, and in many parts of prehistoric Africa, flexible herding systems developed long before farming (Marshall and Hildebrand 2002). The evidence from Africa contrasts with classic examples of the so-called Neolithic Revolution in the Middle East, East Asia, and parts of the Americas, where agriculture is seen as driving a transition from foraging toward more complex forms of (sedentary) social life (but see, for example, Zeder [2011]). In these areas, archaeologists have a wealth of information on village life, food production and consumption, and social behaviors such as communal feasting or other ritual practices. These topics are understudied for smaller-scale mobile societies, where emphasis has largely been on explaining foraging and pastoralism as ecological adaptations (for a critique, see Makarewicz [2013]).

Lack of discussion about pastoralist societies is often attributed to the ostensible invisibility of mobile communities, who maintain relatively few possessions and thus presumably leave few traces in the archaeological record. Throughout the world, investigations of mobile pastoralism have by now generated a significant corpus of archaeological data (Honeychurch and Makarewicz 2016). Ethnoarchaeological work (Biagetti 2014; Carrer 2015; Wright 2016) continues to aid in the interpretation of the often substantial and archaeologically recognizable remains left behind, particularly at habitation sites. Advances in biomolecular research are revolutionizing our ability to understand pastoralist subsistence systems (Dunne et al. 2012) and herd management practices (Janzen 2015). Yet the lives of mobile pastoralists are still, for the most part, conceptualized by archaeologists in terms of how they relate to urban, agricultural populations (see Porter [2012] for discussion of the Near East). In understanding the prehistory of eastern Africa, the study of pastoralism is fundamental: pastoralism formed the foundation of the transition to food production, spread widely, and has persisted as a primary subsistence system in the region over three millennia.

In many ways, though, the eastern African archaeological record subverts expectations for what pastoralism in this region should look like, based on the extensive ethnographic record for the livelihoods of modern, metal-using pastoralist groups. Ethnoarchaeologists have generally found that relatively mobile groups in eastern Africa rarely leave obvious material traces behind when they move (Mbae 1990; Robbins 1973) (but see Grillo [2012]). However, pastoralists do modify their immediate environment in important waysfor example, their animals deposit dung-that may be archaeologically or paleoecologically detectable (Boles and Lane 2016; Lane 2016; Muchiru et al. 2009; Shahack-Gross et al. 2008; Weissbrod 2011). The archaeological record for stone-using pastoralists in eastern Africa is remarkable when viewed in comparison to the ethnographic record for metal-using herders, as the former is characterized by exceptionally materially rich sites.

The 1970s and 1980s were marked by intensive research at such sites, which came to be collectively called "Pastoral

CONTACT Katherine M. Grillo kgrillo@uwlax.edu D Department of Archaeology and Anthropology, University of Wisconsin - La Crosse, 437G Wimberly Hall, La Crosse, WI 54601, USA

* Co-first authors. 
Neolithic" (PN). Excavations revealed PN mortuary and settlement sites dating to ca. 4500-1200 B.P. along the Rift Valley and adjacent plains, stretching from Lake Turkana to Lake Eyasi (FIGURE 1) (Lane 2013). Several of the earliest pastoralist sites in the Turkana Basin around 4500 B.P. are megalithic communal cemeteries; habitation sites are rarer (Grillo and Hildebrand 2013). Herders later spread farther south, into a landscape occupied by diverse hunter-gatherer groups
(Ambrose 1998). At nearly all habitation sites associated with herders, archaeologists documented dense refuse middens containing highly fragmented faunal remains, ceramics, and lithics, sometimes mixed with ash interpreted as burnt dung (Barthelme 1985; Bower et al. 1977; Odner 1972; Robertshaw 1990). Two archaeological groupings are recognized for the herding societies seen in eastern Africa post-3000 B.P., the "Elmenteitan" and the "Savanna Pastoral Neolithic" (SPN)

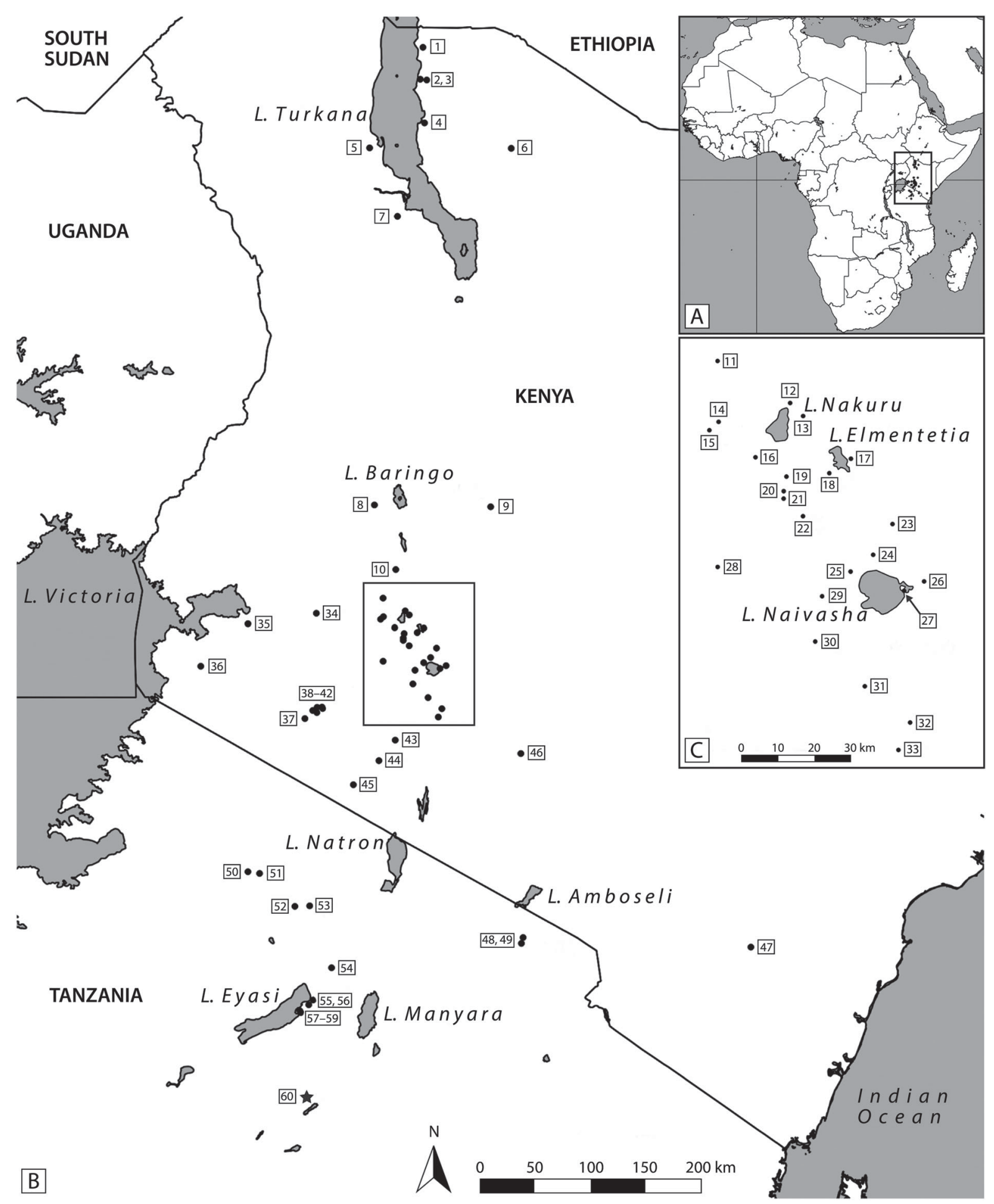

Figure 1. Map of Africa (A) highlighting the region of eastern Africa (B), with the distribution of published Pastoral Neolithic sites and detail (C) of the Central Rift Valley. The star indicates the location of the Luxmanda site. Sites: 1) FwJj25 and FwJj5; 2) GaJi2; 3) GaJi4/Dongodien; 4) Jarigole; 5) Manemanya; 6) North Horr; 7) Lothagam pillar sites; 8) Ngenyn; 9) Kisima Farm sites; 10) Maringishu; 11) Deloraine; 12) Hyrax Hill; 13) Lion Hill Cave; 14) Njoro River Cave; 15) Egerton Cave; 16) Bromhead's Cave; 17) Cole's Burial; 18) Elmenteita; 19) Prolonged Drift; 20) Nderit Drift; 21) Gamble's Cave; 22) Prospect Farm; 23) Gilgil; 24) Marula Rockshelter; 25) Masai Gorge Rockshelter; 26) Naivasha Railway; 27) Crescent Island sites; 28) Remnant; 29) Ndabibi; 30) Enkapune ya Muto; 31) Akira; 32) Salasun; 33) Suswa Lava Tubes; 34) Keringet (ave; 35) Wadh Lang'o; 36) Gogo Falls; 37) Oldorotua sites; 38) Regero; 39) Lemek sites; 40) Sugenya; 41) Ngamuriak; 42) Sambo Ngige; 43) Rotian; 44) Narosura; 45) Olupilukunya; 46) Lukenya Hill sites; 47) Kahinju and Mwiitu; 48) Maua Farm; 49) Wasendo Madukani; 50) Seronera; 51) SWRI; 52) Gol Kopjes; 53) Nasera Rockshelter; 54) Ngorongoro; 55) Mikocheni; 56) Mumba Rockshelter; 57) Gileodabeshta 2; 58) Jangwani 2; 59) Ishimijega Rockshelter; 60) Luxmanda. 
(Ambrose 2001). These groupings are distinct from each other in terms of settlement patterns, mortuary practices, and material culture, but both generally represent specialized pastoralist systems based on the management of cattle, sheep, and goats.

Previous research focused on the necessary work of building a basic PN regional chronology, mainly informed by ceramic styles, lithic technology, and limited radiocarbon dates. Zooarchaeologists investigated the origins of specialized pastoralism (Marshall 1990) and variations in herding and hunting strategies (Gifford et al. 1980). Many aspects of early pastoralist life remained relatively little explored, including inter- and intra-site settlement patterns, culinary practices (especially involving plant use), and forms of social organization based on gender, age, or other factors (but see, for example, Gifford-Gonzalez [1998a] and Goldstein and Munyiri [2017]). Most excavations at settlement sites were limited to small test trenches, with exceptions at the Kenyan sites of Narosura (an SPN site) (Odner 1972) and especially Ngamuriak (an Elmenteitan site) (Robertshaw and Marshall 1990), where extensive horizontal excavations exposed features such as hearths and a house floor.

The recent discovery of Luxmanda, an SPN site in northcentral Tanzania, suggests that large, spatially differentiated pastoralist sites may have been the norm earlier and throughout a larger part of eastern Africa than previously thought. Luxmanda lies well south of the previously known extent of all PN sites, challenging notions that a "frontier" between stone-using herders and hunter-gatherers long persisted across northern Tanzania (Lane 2004; Prendergast 2011). This frontier is envisioned as a place where herders would have encountered new risks, such as zoonotic diseases, and where reliance on foraging (and foragers) might have helped mitigate that risk (GiffordGonzalez 1998b, 2000). Until now, the evidence for PN-era herders has been sparse in northern Tanzania (compare $>70$ published sites with PN materials in Kenya versus 13 in Tanzania), and sites are marked by thin deposits, few diagnostic ceramics, and evidence for mixed hunting and herding (Prendergast 2011). This scarcity has supported arguments that herders on the "frontier" are even less archaeologically visible than robust, specialized groups in the "core." We now have evidence to the contrary, and we argue that the long-standing emphasis on and support for research in Kenya, compared with Tanzania, has skewed our understanding of pastoralism's spread throughout this region.

In this paper, we present findings from two excavation seasons at Luxmanda, now the largest and southernmost documented PN-era settlement site. A suite of radiocarbon dates forces us to reconsider the speed and extent of herding's spread during the PN. The ability to conduct a long-term research program at Luxmanda also enables investigation of daily life at an early pastoralist site in a way that has not been possible during previous research schemes. By combining new and old survey techniques and a wide array of postexcavation analyses, our study sheds light on aspects of daily life such as spatial organization, subsistence, technology, and exchange networks. Luxmanda offers a window into the lives of specialized pastoralists who, in fact, might not have lived at the edge of a "frontier," but rather within an extensive web of similarly specialized communities, and who are quite archaeologically visible, provided one looks.

\section{Background to the Study Area and Prior Research}

The Luxmanda site (UTM 36M 0757353, 9529048; 1878 masl) is located near a village of the same name (pop. 3208; Babati District), at the southern edge of the Mbulu Plateau, or Mbulu highlands (FIGURE 2). The village is perched just $8 \mathrm{~km}$ north of the Rift escarpment, below which lies the alkaline Lake Balangida (1531 masl), and just beyond the lake, the extinct volcano Mount Hanang (3420 masl). The perennial Ufana River, less than $2 \mathrm{~km}$ from the village, provides the nearest fresh water, in addition to several springs. Luxmanda's cool, moist climate is ideal for farming and grazing. A 2012 census (observed in the Ufana ward office) showed that goats (Capra hircus) dominate the livestock (61\%), followed by cattle (B. taurus or taurus/indicus crossbreeds) (17\%), sheep (Ovis aries) (17\%), and donkeys (Equus asinus) (5\%). Maize and beans are the dominant crops in the region, with supplementary cultivation of African cereals like sorghum and millet (United Republic of Tanzania 2012).

The Mbulu highlands are home to the agro-pastoralist Iraqw, and the area has been subject to recent studies of agricultural intensification (Börjeson 2004). For earlier periods, however, there has been virtually no archaeological or paleoecological research. An exception is the work of Mabulla and Gidna (2015), who have documented numerous rockshelters, often with paintings, in the hills near Luxmanda as well as below the escarpment. Several have been excavated, including Endadu Rockshelter (Mjema 2008) and Daumboy Rockshelter 3 (Prendergast et al. 2013); the latter has early Holocene Later Stone Age (LSA) deposits and late Holocene deposits containing small numbers of potsherds and, rarely, domestic cattle among the wild fauna. About $80 \mathrm{~km}$ north of Luxmanda lies Lake Eyasi and its well-documented PN occupations (Mehlman 1989; Prendergast 2011), until now the southernmost evidence for stone-using pastoralists in eastern Africa.

Luxmanda was discovered in 2011 by Gidna, who observed ceramics and lithics eroding from a road cut. The site lies under a series of farm plots, and parts have been consequently destroyed; additionally, prehistoric cultural deposits have been used in recent house construction. In 2012, 24 shovel test pits (STPs) were excavated in a $60 \times 100 \mathrm{~m}$ grid (Prendergast et al. 2013) (FIGURE 3). Those STPs produced ceramics strongly resembling those found at the Narosura site in Kenya (Odner 1972), indicating that Luxmanda material might likewise be classified as SPN (Ambrose 2001). Organic matter (OM) in one sherd was AMS radiocarbon dated to $2855 \pm 20$ B.P. (3000-2845 CAL B.P.; ISGSA2367), which falls within the range generally recognized for SPN settlements in the Central Rift Valley (Lane 2013). These results prompted our returns in 2013 and 2015.

\section{Methods}

In 2013, the main goals were preliminary investigations of the site's lateral extent, its stratigraphy, and its chronology. Two sources of information determined placement of excavation units (FIGURE 3): the results of the 2012 STP grid, and stratigraphy observed in a pit latrine that was being constructed during fieldwork. Unit $1(2 \times 2 \mathrm{~m})$ was placed in an area of the STP grid with high artifact density, and Unit $2(2 \times$ $2 \mathrm{~m}$ ) was placed near the latrine. An organic-rich midden with dense faunal, ceramic, and lithic material appeared to 


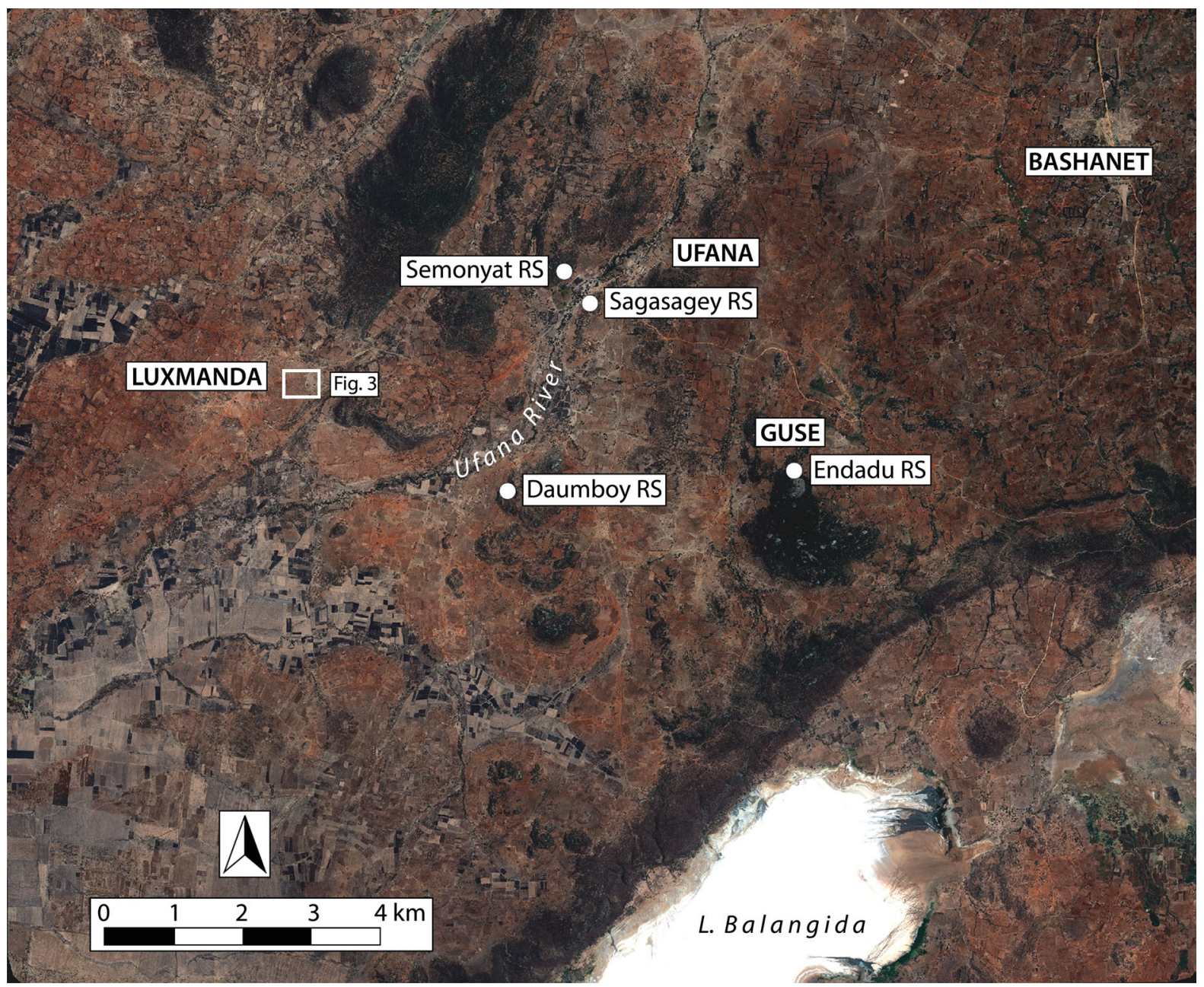

Figure 2. The study area, showing population centers (in capital letters) and archaeological sites (RS= rockshelter). SPOT 1.5 resolution imagery licensed to M. Prendergast courtesy of Harvard University Center for Geographic Analysis.

extend across the site, sloping to the northwest. Two additional $1 \times 1 \mathrm{~m}$ units ( 3 and 4 ) were opened in that direction, and Unit 5 (also $1 \times 1 \mathrm{~m}$ ) was placed in an ashy area to the southwest with particularly abundant surface finds.

In 2015, research goals shifted toward developing a more detailed understanding of both the site's lateral extent and its internal spatial differentiation, particularly within the midden area. Gifford-Gonzalez (2014) had noted that PN-era middens, being extensive and apparently undifferentiated, as well as the product of multiple households, are remarkably distinct from those of modern pastoralist groups. With this in mind, the 2015 fieldwork coupled surface, auger, and nearsurface geophysical surveys with targeted exploratory excavations to better understand the true distribution, uniformity, and continuity of midden deposits.

Permissions were granted by landowners to investigate much, but not all, of the ca. 3 ha area in which fieldwalking recovered surface finds. Within the permitted area, a $20 \mathrm{~m}$ grid was established with a Leica total station as the basis for three survey methods: auger cores $(10 \mathrm{~cm}$ diameter $)$ and $1 \mathrm{~m}^{2}$ dogleash surface collections were taken at the grid corners (and more densely in some areas in order to more precisely delimit the subsurface deposits) and a magnetic gradiometry survey was conducted over the bulk of the gridded area (FIGURE 3A). Each auger core produced a continuous record of natural and cultural deposits from surface to sterile subsoil. Descriptions of sediments and archaeological deposits, as well as counts and weights of archaeological lithics, ceramics, and bone, were recorded. Augering continued outward from the core area of the site in all directions until neither surface collection nor augering had recovered any cultural material at two consecutive points; ultimately 151 auger cores were recorded over an area of approximately $43,000 \mathrm{~m}^{2}$. Magnetic gradiometry survey with a Bartington Grad-601 Fluxgate Gradiometer was carried out over two areas, capturing both the core site area and outlying areas identified by surface and auger survey, covering more than $35,360 \mathrm{~m}^{2}$ in total. This geophysical survey demonstrated a spread of ferrous magnetic anomalies across the site, several potentially modern pit or ditch features, and a cluster of large thermoremanent magnetic anomalies at least $5 \mathrm{~m}$ in diameter, indicative of multiple sources of intense burning. Detailed methods and results of the geophysical survey will be reported fully elsewhere. The combined survey methods demonstrated the site's area to be greater than $30,000 \mathrm{~m}^{2}$, much larger than the reported dimensions of other PN sites: Narosura was estimated to extend across ca. $8400 \mathrm{~m}^{2}$ (Odner 1972: 30); Ngamuriak was reported as "well over" $100 \mathrm{~m}$ in diameter, i.e., well over $7854 \mathrm{~m}^{2}$ (Robertshaw and Marshall 1990: 54); and Prolonged Drift (GrJi1) appears to be greater than ca. $2700 \mathrm{~m}^{2}$ based on illustration (Gifford et al. 1980) (FIGURE 3).

The results of surface collection, augering, and magnetic survey led us to target an area of the site where thermoremanent magnetic anomalies and subsurface finds were abundant, and where the area had been protected from plowing damage 


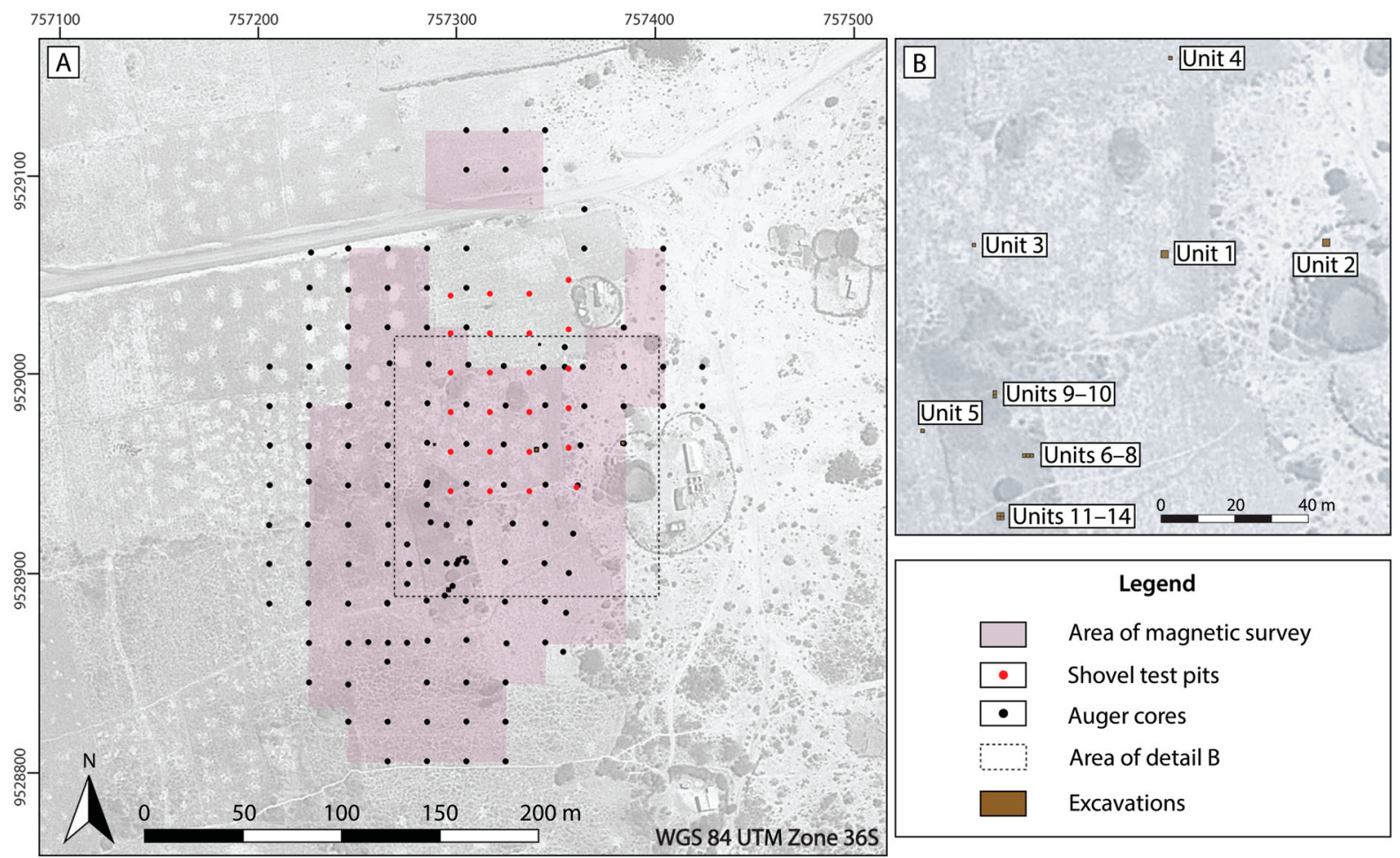

Figure 3. A) Plan of the Luxmanda site indicating 2012 shovel test pit (STP) grid, 2013 and 2015 excavation units, and 2015 auger and magnetic survey grids. B) Detail of the excavation units. Background imagery is derived from a 9/1/2012 Digital Globe image available from Google Earth. Excavation units are to scale; points indicating STPs and auger cores are not to scale.

and aeolian erosion by grassy pasture. Landowners informed us that, in living memory, this area had not been farmed, as the grassy patch was intentionally maintained for pasture and thatched-roof material. We outlined a series of three trenches aligned to the site grid, subdivided into $1 \times 1 \mathrm{~m}$ units (Units 6-8 together formed a $3 \times 1 \mathrm{~m}$ trench, Units 910 a $1 \times 2 \mathrm{~m}$ trench, and Units $11-14$ a $2 \times 2 \mathrm{~m}$ trench).

In both the 2013 and 2015 campaigns, excavation followed natural stratigraphy, subdivided into arbitrary $5 \mathrm{~cm}$ spits where exceeding this thickness, or where stratigraphy was not easily detectable. All deposits were dry sieved using nested 2 and $5 \mathrm{~mm}$ mesh, except for samples selected for bucket flotation, followed by wet sieving. In 2013, flotation samples were taken mainly in the midden deposits. In 2015, flotation samples were taken for one column in each of the three trenches (one ca. $12 \mathrm{~L}$ bucket per $5 \mathrm{~cm}$ spit in each trench), and also from features of interest, such as the possible hearths, in which case the complete matrix was collected. After dry sieving to remove OM and rocks, which reduced column samples of 8 to $10 \mathrm{~L}$, the samples were agitated in water and poured through fabric suspended over $0.5 \mathrm{~mm}$ geological sieves. This process was repeated until no floating material was observed on the surface of the water. The heavy fraction was then wet sieved through $1 \mathrm{~mm}$ mesh. Analyses of paleobotanical remains are ongoing and will be reported elsewhere; the same is true of bulk sediment and micromorphology column samples collected in Units 8 and 11. Except for samples exported for these and other specialist analyses, all materials from the excavations are stored at the National Museum and House of Culture in Dar es Salaam.

\section{Excavation Units and Stratigraphy}

The sections below describe stratigraphy for all units excavated in 2013 and 2015. Datum points referenced in the text are specific to each excavation unit, and are variable. For Units 1-5, a datum was established at the highest surface point of each unit. For Unit 1, this lies at 1879.65 masl (meters above sea level), and for Unit 2, at 1881.2 masl. The Unit 3 datum is 1877.76 masl, the Unit 4 datum is 1880.18 masl, and the Unit 5 datum is 1876.61 . For Units 6-8 and 9-10, a single datum was established at 1877.5 masl; for Units 11-14, a datum was established $60 \mathrm{~cm}$ lower at 1876.90 masl. For ease of comparison, two measurements are provided here: below datum (bd), as originally recorded, and masl.

\section{Units $1-5$}

Units 1-4 shared broadly parallel stratigraphy. The uppermost $20 \mathrm{~cm}$ of Unit 1 consist of a plow zone of loose, organic-rich dark brown sandy silt. Below this deposit lies a more compacted, dark yellowish-brown, slightly sandy silt. This deposit spans ca. 25-42 cm bd (1879.4-1879.23 masl), and was particularly artifact-rich; this increase in ceramic, lithic, and faunal densities is illustrated in Supplemental Material 1. Bone and ceramics in this deposit were heavily fragmented. This deposit has a more diffuse lower boundary, grading into a heavily termite-burrowed layer with less cultural material. This underlying deposit, at ca. $42-72 \mathrm{~cm}$ bd (1879.23-1878.93 masl), is also a dark yellowish-brown sandy silt, but is marked by reddish-brown inclusions originating in the underlying weathered bedrock; these inclusions become more abundant with depth. Penetrating into this deposit is a pit containing cattle limb bone fragments from a large individual, and little other cultural material. The deepest layer of Unit 1, from ca. $72-105 \mathrm{~cm}$ bd (1878.93-1878.6 masl), is near-sterile, reddish-brown weathered bedrock.

Unit 2 mirrors Unit 1, with a plow zone from the surface to ca. $29 \mathrm{~cm}$ bd (1880.91 masl), an artifact-rich deposit as 


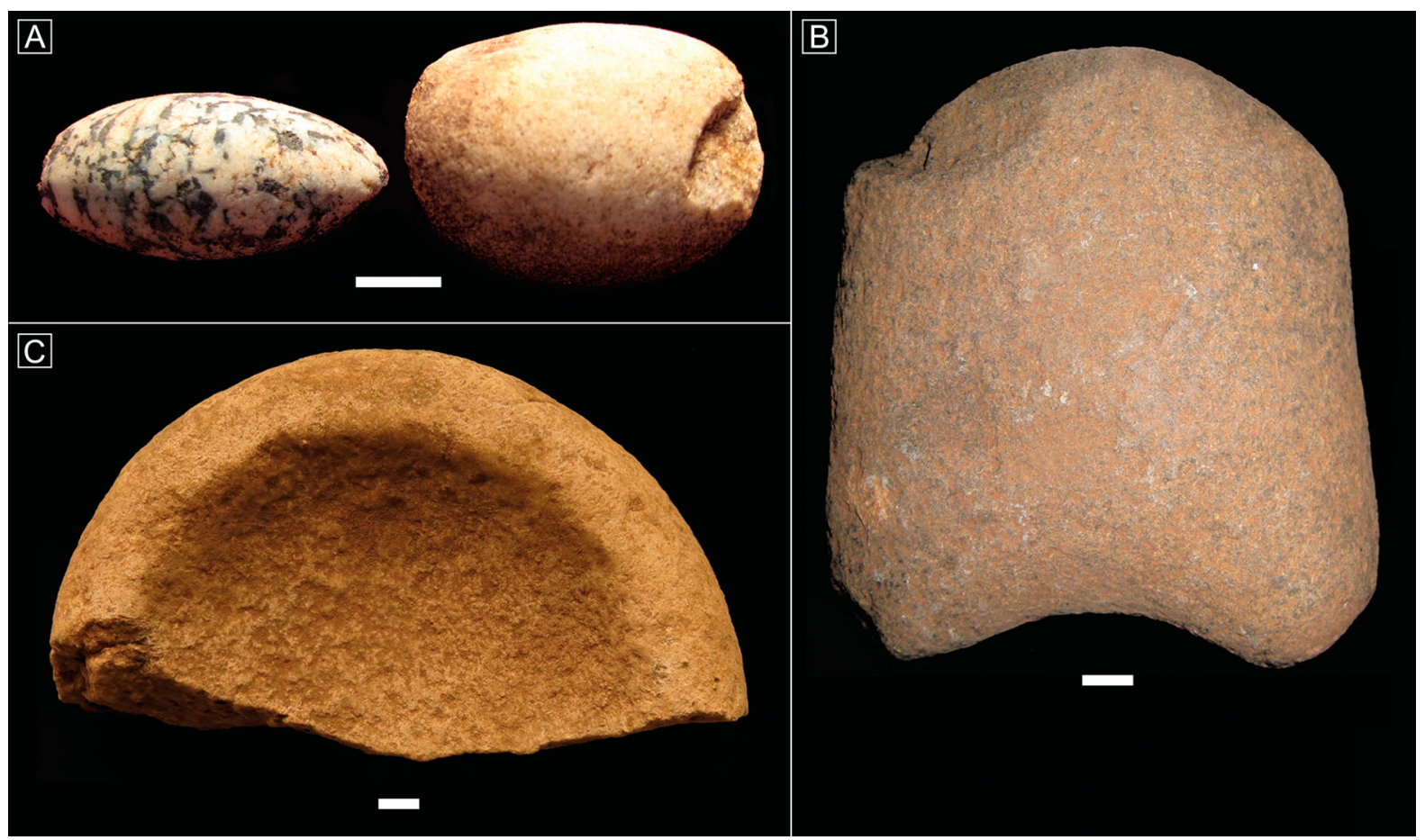

Figure 4. Groundstone artifacts from Luxmanda; A) ovoid grinding stones recovered in situ in Unit 2; B) "axe" found on the surface; C) stone bowl fragment found on the surface.

described above to ca. $41 \mathrm{~cm}$ bd (1880.79 masl), and a less artifact-dense deposit, heavily altered by burrowing and weathered bedrock inclusions, below that to $\mathrm{ca} .51 \mathrm{~cm} \mathrm{bd}$ (1880.69 masl) (sUPPLEMENTAL MATERIAL 2). A near-sterile, reddish-brown layer of weathered bedrock separates this deposit from the bedrock itself, but is so thin (generally < $2 \mathrm{~cm}$ ) that it was only visible after excavation. Ceramics and bones are less fragmented than in Unit 1, permitting greater reconstruction and identification; in some parts of the midden deposit, they are heavily concentrated in one area of the trench. Ceramic, lithic, and faunal densities in the artifact-rich deposit were similar overall to those in Unit 1. Notably, two small ovoid groundstone objects were found in Unit 2 (FIGURE 4A).

Although the stratigraphy in Units 3 and 4 was similar to that of Units 1 and 2, artifact densities were much lower: in Unit 4 there was a slim concentration of material just thick enough to be seen in the profile, while in Unit 3 such a concentration could not be detected. Both units reached sterile weathered bedrock subsoil within $55 \mathrm{~cm}$ below surface.

Unit 5 was located in an area of abundant surface materials (including groundstone axes) in a loose, light gray, powdery, ash-like matrix. The immediate area had been recently farmed, and excavation confirmed that there had been significant stratigraphic disturbance; the abundance of surface materials is at least partly attributable to this activity. The top ca. $10 \mathrm{~cm}$ of the subsurface comprise the plow zone, similar to that described above, while the underlying deposits, ca. $20-70 \mathrm{~cm}$ bd (1876.4-1875.9 masl), are characterized by the same light gray ash-like material visible on the surface, which we currently interpret as decayed dung (see description for Units 11-14). These deposits are mixed with other refuse, including artifacts and some burned bone, and are heavily burrowed. Jumbled cultural material is found throughout with no clear orientation or concentration, though in general artifacts are most abundant in the upper part of the deposit.
As with other trenches, the Unit 5 faunal assemblage is dominated by domestic caprines and cattle; while wild fauna are slightly more common in Unit 5 than elsewhere, most of these specimens appear (based on their pristine condition) to be intrusive, derived from modern contexts. Most artifacts are coated in a heavy carbonate concretion, possibly due to water percolating through decayed dung and/or ash, while many of the wild faunal remains are notably free of concretions. The light gray deposits overlie a reddish-brown clayey silt derived from weathering of the bedrock, initially visible at ca. $70 \mathrm{~cm}$ bd (1875.9 masl). Excavation was stopped at ca. $75 \mathrm{~cm}$ bd (1875.85 masl) as the deposit was nearly sterile.

\section{Units 6-8}

Units 6-8 were placed in a $3 \times 1 \mathrm{~m}$ formation in the center of the aforementioned grassy patch identified through magnetic and auger survey as having high archaeological potential. Their upper contexts (for that of Unit 8, see FIGURE 5) follow a similar sequence to that of Units 1 and 2, in that a root-disturbed A-horizon (ca. 10-20 cm thick) overlies a darker, artifact-rich deposit (ca. $30-40 \mathrm{~cm}$ thick). This artifact-rich deposit is initially visible as flecks of bone and charcoal within a yellowish-brown sandy silt, which has a mottled appearance, caused by patches of reddish matrix likely brought by termites from the underlying deposits. As shown in FIGURE 5, a major spike in artifact density occurs around 45$60 \mathrm{~cm}$ bd (1877.05-1876.9 masl). The artifact-rich layer is nevertheless patchy rather than uniformly distributed across the trench, and slopes slightly from west to east. Under this layer, a compact matrix of silt with fine sand contains comparatively few artifacts, and there is increased evidence for insect and rodent activity, including hardened termite burrow and/or root casts. Patches of ash and small quantities of burned bones are observed in these termite-disturbed deposits, particularly in the southern part of Units 6-8, and 


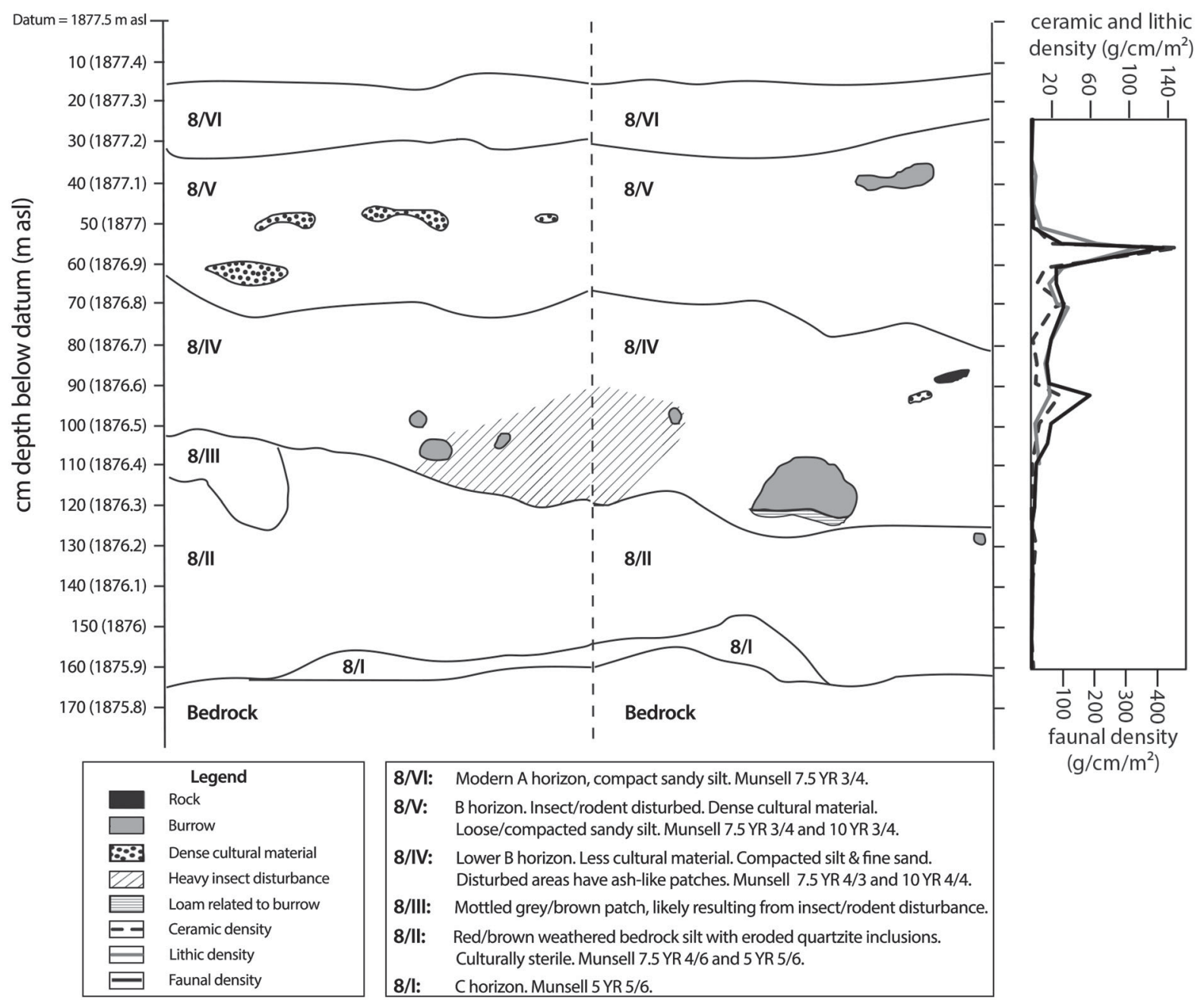

Figure 5. Unit 8 south and west profiles, with Unit 8 artifact densities by depth.

especially around $70-75 \mathrm{~cm}$ bd (1876.8-1876.75 masl), but it is not clear whether these are in situ or are the result of this bioturbation. At this depth, excavation was stopped in Units 6-7 due to extensive termite disturbance.

The deposit in Unit 8 has low artifact densities, small patches of ash, and minor termite activity until a depth of ca. $90 \mathrm{~cm}$ bd (1876.6 masl), where a discrete patch of bones is found. Lithics and ceramics are also more abundant from $90-100 \mathrm{~cm}$ bd (1876.6-1876.5 masl), occasional charcoal flecks are found, and the southern part of the unit is particularly soft and ashy. Given that the main artifact-rich deposit is located ca. $30 \mathrm{~cm}$ above these concentrations, we interpret them as possibly belonging to an earlier and unrelated depositional event, albeit one producing much less cultural material. Notably, a radiocarbon date on unidentified wood charcoal from this context is comparable to dates obtained on the levels that are characterized by high artifact density in units 9 and 10 (see Table 1 and discussion below). This suggests that the two discrete episodes of refuse disposal in Unit 8 happened in relatively quick succession, and the accumulation of silt and fine sand (likely aeolian) in between was relatively rapid. Below ca. $100 \mathrm{~cm} \mathrm{bd}$ (1876.5 masl), the weathered bedrock in Unit 8 becomes nearly sterile, burrow-ridden, and increasingly reddishbrown. The deepest cultural material, just above bedrock at ca. $160 \mathrm{~cm}$ bd (1875.9 masl), consists of a few heavily concreted, poorly preserved bones.

\section{Units 9-10}

Units 9-10 were placed in a $1 \times 2 \mathrm{~m}$ formation $15 \mathrm{~m}$ north of Units $6-8$ in order to investigate strong bipolar magnetic anomalies, at least $5 \mathrm{~m}$ in diameter, interpreted as likely thermoremanent signals of intense burning. As in Units 6-8, a root-disturbed A-horizon overlies the main archaeological deposits. There is likewise a major increase in artifact density in Units 9-10 below the A-horizon, at the same depth below surface and elevation as in Units 6-8, in a layer of yellowbrown sandy silt ca. $45-75 \mathrm{~cm}$ bd (1877.05-1876.75 masl) (FIGURE 6). In Units 9-10, below this layer is another artifact-rich deposit of sandy silt, but light and dark gray in color. Occasional charcoal and burned bone is found within this deposit, and we attribute the gray colors to an ash component, given that this layer directly overlies two burned earth features. In Unit 9, one feature is marked by reddish/ orange hardened, likely heat-altered, sandy silt with a clay component, in a shallow circular or semi-circular depression (SUPPlemental MATERIAL 3). The center of this depression is filled with a silty ash, with a minor sand component. In Unit 10, a more ephemeral ashy deposit occurs directly above another concentration of burned earth. We interpret these features as hearths, and they are visible in these units' east profile at roughly the same depth and directly above reddish-brown subsoil (FIGURE 7), suggesting contemporaneity or near-contemporaneity. Additional concentrations of 
Table 1. AMS radiocarbon dates from Luxmanda.

\begin{tabular}{|c|c|c|c|c|c|c|}
\hline Unit & Context & Material & Lab No. & UNCAL B.P. & CAL B.P. & Notes \\
\hline 2 & $\begin{array}{l}\text { Layer III, spit } 8,40-45 \mathrm{~cm} \text { bd } \\
\quad(1880.8-1880.75 \text { masl })\end{array}$ & Tooth apatite & ISGS-A2819 & $2145 \pm 25$ & $2152-2007$ & Caprine upper M3, below bone midden \\
\hline 1 & $\begin{array}{l}\text { Layer III, spit } 13,63-68 \mathrm{~cm} \text { bd } \\
\quad(1879.02-1878.97 \mathrm{masl})\end{array}$ & Tooth apatite & ISGS-A2818 & $2395 \pm 25$ & $2486-2322$ & Cattle upper P4, base of bone pit feature \\
\hline 1 & $\begin{array}{l}\text { Layer II, spit 5, 30-32 cm bd } \\
\quad(1879.35-1879.33 \text { masl })\end{array}$ & Tooth apatite & ISGS-A2817 & $2515 \pm 25$ & 2719-2379 & Cattle lower P3, near top of midden \\
\hline 2 & $\begin{array}{l}\text { Layer II, spit 7, 35-40 cm bd } \\
\quad(1880.85-1880.8 \text { masl) }\end{array}$ & $\begin{array}{l}\text { Tooth dentin } \\
\text { collagen }\end{array}$ & ISGS-A2940 & $2580 \pm 25$ & 2749-2492 & Cattle upper $\mathrm{P} 2$, base of bone midden \\
\hline STPB5 & Shovel test pit & Ceramic OM & ISGS-A2367 & $2855 \pm 20$ & $3000-2845$ & $\begin{array}{l}\text { Decorated rimsherd, Narosura tradition. } \\
\text { STP = shovel test pit ( } 2012 \text { season), no depth. }\end{array}$ \\
\hline 9, SE & Level 10, $70 \mathrm{~cm}$ bd (1876.8 masl) & Charcoal & ISGS-A3798 & $2880 \pm 20$ & $3056-2862$ & Hearth feature \\
\hline $9, \mathrm{NW}$ & Level 8, $60 \mathrm{~cm}$ bd (1876.9 masl) & Charcoal & ISGS-A3797 & $2900 \pm 20$ & $3065-2877$ & Ashy deposit in NW quad \\
\hline $8, \mathrm{NE}$ & Level 17, $100 \mathrm{~cm}$ bd (1876.5 masl) & Charcoal & ISGS-A3796 & $2905 \pm 20$ & $3069-2878$ & Cluster of faunal remains also found in this context \\
\hline $10, \mathrm{NE}$ & Level 12, 78 cm bd (1876.72 masl) & Charcoal & ISGS-A3799 & $2905 \pm 20$ & $3069-2878$ & Ashy deposit in SE quad \\
\hline $10, N E$ & Level $17,115 \mathrm{~cm}$ bd (1876.35 masl) & Bone collagen & ISGS-A3806 & $2925 \pm 20$ & $3141-2890$ & Petrosal of human infant \\
\hline 2 & $\begin{array}{l}\text { Layer II, spit } 5,29-33 \mathrm{~cm} \text { bd } \\
\quad(1880.91-1880.87 \text { masl })\end{array}$ & Ceramic OM & ISGS-A2820 & $2960 \pm 25$ & $3164-2960$ & Decorated rimsherd, Narosura tradition \\
\hline
\end{tabular}

Note: Calibrated using the SHCal13 curve (Hogg et al. 2013) in Oxcal v.4.3 (Bronk Ramsey 2009), 95.4\% Cl.

what appears to be ash (without visible associated burned earth) are found in the northwestern quadrant of Unit 9, along the northern edge of Unit 9, and along the eastern profile of Unit 10. Only one circular concentration of ash with very diffuse edges was found completely within the excavated area, in the north-center of Unit 10 at the same depth as the burned earth features. The very edge of a pit is visible in the center of the east profile of Unit 10, cutting ca. $13 \mathrm{~cm}$ down from the same level as the burned earth features into weathered bedrock subsoil.

These limited exposures suggest that multiple hearths were built in this small area over a relatively short period of time, perhaps cleaned of ash that was discarded nearby, and that a layer of domestic refuse was shortly thereafter strewn across this surface. Directly below these hearths and other ashy features is the same reddish-brown weathered bedrock subsoil present in the other excavation units described thus far. A human infant was discovered in the reddish-brown subsoil of Unit 10 at ca. $115 \mathrm{~cm}$ bd (1876.35 masl), just to the west and ca. $35 \mathrm{~cm}$ below the burned earth feature visible in the east profile of Unit 10. Although no pit for the burial or stratigraphic disturbance to the subsoil was visible during excavation, the relative positions of the burial and the burned earth feature suggest a direct association. This discovery represents the earliest evidence for residential burial in eastern Africa; we note that some (historically unrelated) pastoralist groups in eastern Africa today inter infants behind hearths (Straight 2006) or under sleeping hides (Spencer 1973) within their houses.

\section{Units 11-14}

Units 11-14 were placed in a $2 \times 2 \mathrm{~m}$ formation $15 \mathrm{~m}$ south of Units 6-8, also in an area of strong thermoremanent

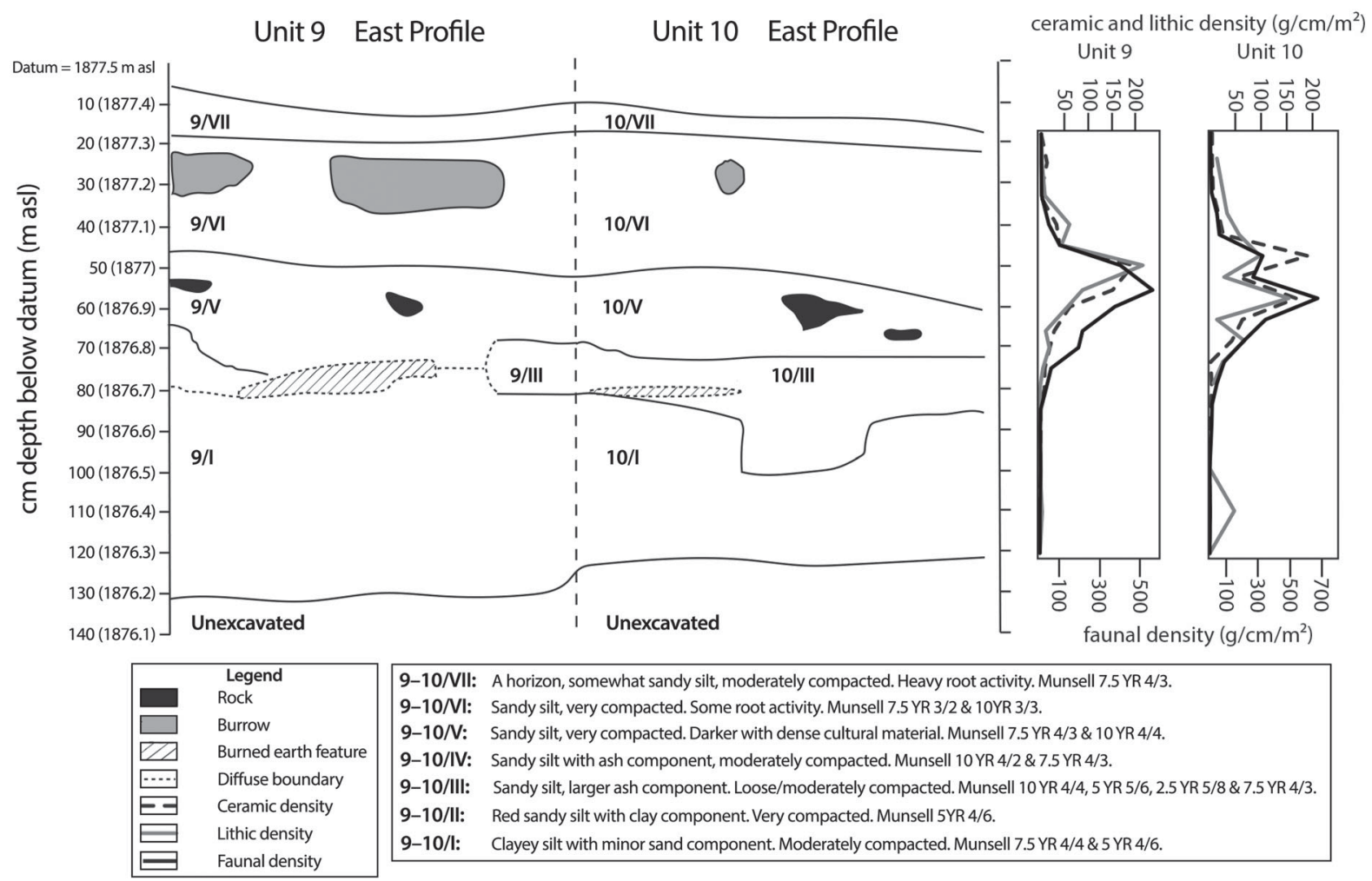

Figure 6. Units 9 and 10 east profiles, with Units 9 and 10 artifact densities by depth. 


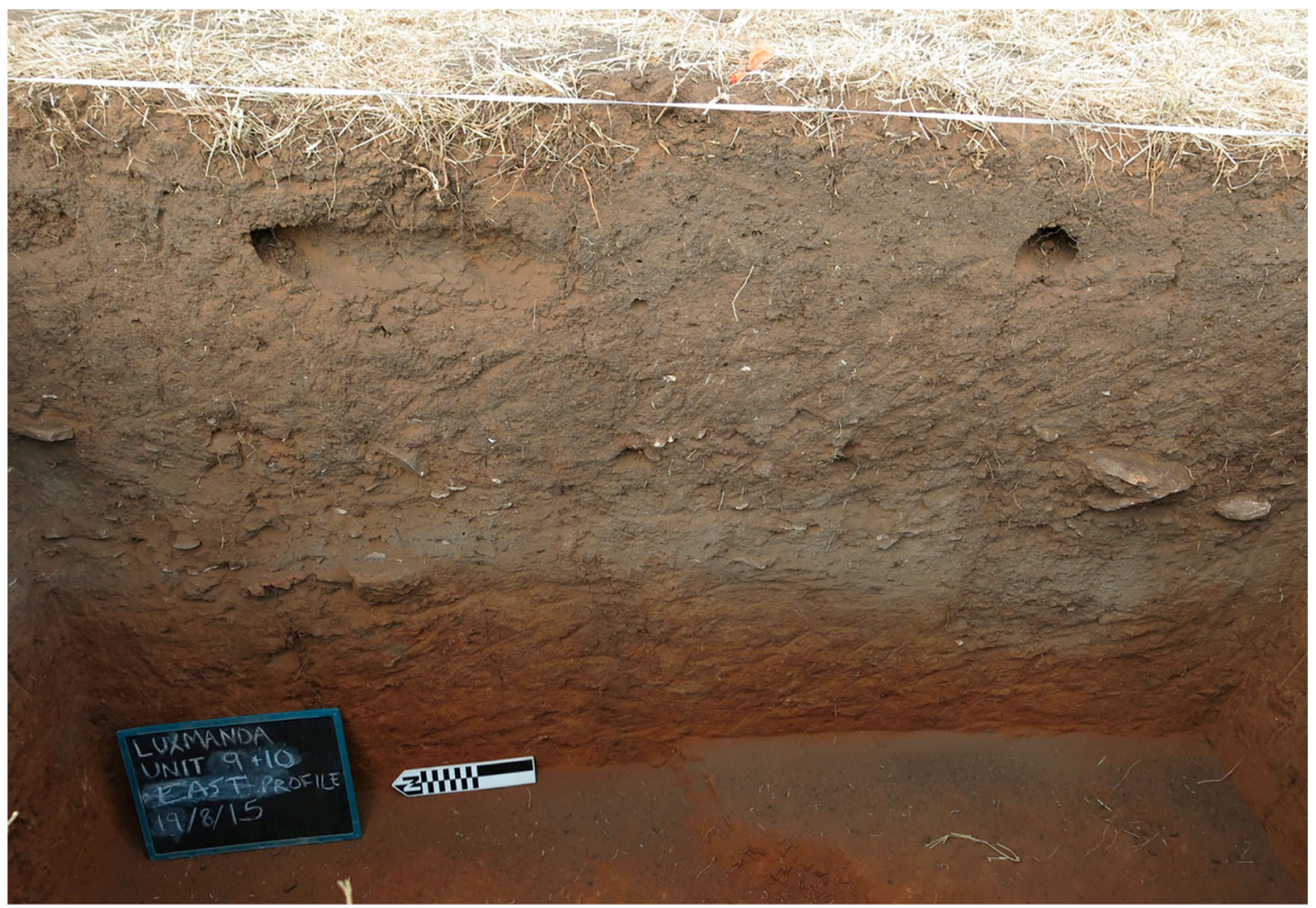

Figure 7. Photograph of east profile of Units 9-10.

magnetic anomalies. The deposits in these units were distinct from those of Units 6-10, but closely resembled deposits in Unit 5. The A-horizon is characterized by a loose, root-disturbed, light gray, powdery deposit. Below this, a more compacted light gray layer was exposed across the trench at ca. $30-35 \mathrm{~cm}$ bd (1876.6-1876.55 masl). The compacted nature of this layer may indicate consolidation due to percolating water. Within and below the compacted layer is another thick, homogenous layer of loose, light gray, powdery sediment. Artifacts in these deposits are abundant, and as in Unit 5, these include large amounts of bone completely coated in a thick concretion. Preliminary analysis of micromorphological thin sections indicates that at least some bones are burnt. However, the deposits did not result from an in situ burn: charcoal is scarce, no other artifacts are obviously burned, and there is no evidence of heating in the surrounding deposits. Our working hypothesis, pending future geochemical and geophysical confirmation (as recommended by Shahack-Gross [2011]), is that these deposits instead represent decayed dung.

Due to the volume of material emerging and to massive insect disturbance, work was stopped in Units 12-14 at ca. $40 \mathrm{~cm}$ bd (1876.5 masl), and continued only in Unit 11 (FIGURES 8 and 9). In this unit, the gray deposit becomes increasingly loose and disturbed with depth, with evidence of activity by both termites and small vertebrates. Occasional inclusions of reddish-brown weathered bedrock appear beginning at ca. $60 \mathrm{~cm}$ bd (1876.3 masl), below which there is a gradual transition to sterile weathered bedrock subsoil at ca. $100 \mathrm{~cm}$ bd (1875.9 masl). In Unit 11 -as in Unit 5there is an overall trend of decreasing artifact density with depth, but the densities of lithics, fauna, and ceramics are not closely linked (FIGURE 9). By contrast, in Units 1-2 and
6-10, densities of these three artifact classes track one other closely, and display distinct spikes that suggest the presence of midden deposits (FIGURES 5,6 and 9) (SUPPLEMENTAL MATERIALS 1 and 2).

\section{Site-wide summary and interpretation of depositional history}

An abrupt, site-wide stratigraphic transition between the weathered bedrock stratum and the overlying anthropogenic stratum suggests that the first detectable evidence for human occupation occurred very shortly after a marked shift in the local environment, possibly the development of grassland ecologies during a transition from arid to increasingly wetter conditions after 4000 B.P. (Ambrose and Sikes 1991; Thompson et al. 2002). This is consistent with ${ }^{14} \mathrm{C}$ dates from the site, discussed below. A period of relatively continuous occupation by a pastoralist population then included the establishment of multiple hearths in at least one area with an infant burial below, and elsewhere the extensive deposition of dung (mixed with some domestic refuse in discrete areas). Domestic refuse was also widely discarded to form dense middens. Auger and excavation results notably indicate that neither dung nor midden deposits are continuous or uniform across the site, but they are common and found in spatially discrete areas. People apparently discarded refuse and penned livestock in household-specific or otherwise very localized areas. The uneven spatiotemporal deposition might also suggest intermittent occupation of the site or regular reorganization of living space within the site. In some areas, aeolian and anthropogenic sediments seem to have accumulated relatively quickly as pastoralists occupied the site, but additional research is needed to refine the chronology of 


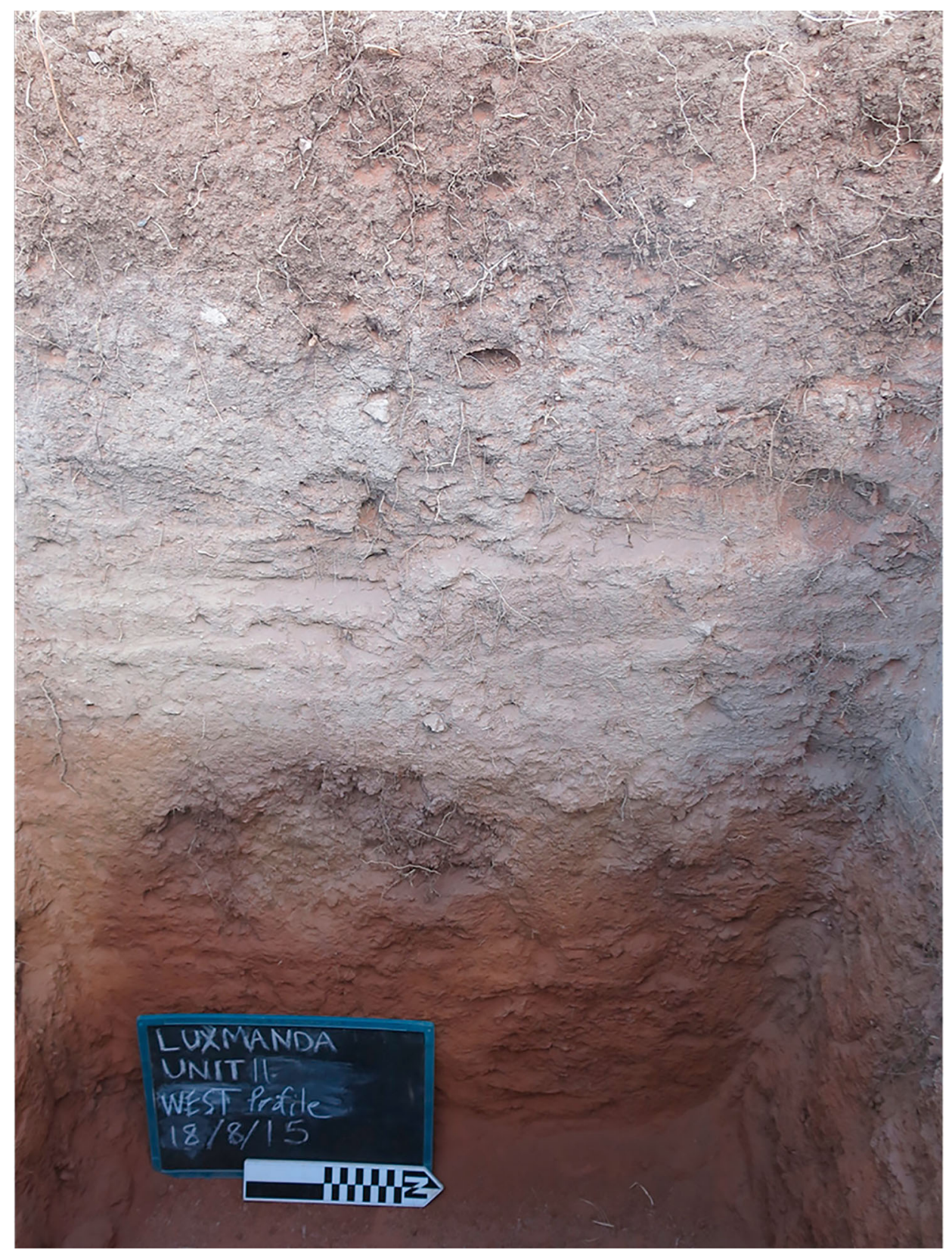

Figure 8. Photograph of west profile of Unit 11 showing thick, ash-like dung deposit.

PN occupation (see below). Luxmanda was eventually abandoned for unknown reasons, after which aeolian sediment deposition continued, shallowly burying the site until plowing and consequent aeolian erosion exposed PN sediments in recent years. Despite the fact that the site has been occupied and farmed continuously in living memory, there are remarkably few detected traces of structures (or refuse) associated with any post-PN communities, except for the currently occupied houses at the site's edge, and one thermoremanent magnetic anomaly identified in the geophysical survey, believed to represent a destroyed modern structure. In the following sections, we provide an overview of the PN domestic refuse found at Luxmanda.

\section{Lithic Technology}

The 2013 lithic assemblage from Units 1-5 was not analyzed, but basic in-field counts show that these units contained 8404 specimens, mostly of chert (47\%) and quartz (46\%) (SUPPLEMENTAL MATERIAL 4). The larger 2015 assemblage from
Units 6-14 (Figure 10) (SUPPLEMENTAL MATERIALS 5-7) was systematically analyzed and found to include 11,266 specimens, $93 \%$ of which are fragmentary debitage $(<5 \mathrm{~mm})$. Units $6-14$ have raw material ratios that are nearly identical to one another and are similar to those of Units $1-5$, with $44.5 \%$ chert and $52.7 \%$ quartz (both vein- and cobble-derived); the remaining small fraction consists of obsidians and coarse lavas. The cherts are coarse gray, white, and brown varieties that are distinct from types commonly found at LSA sites in the broader region (Mehlman 1989), and were likely obtained from a presently unknown source near the site.

Samples of the obsidian artifacts from both field seasons were selected for geochemical characterization using X-ray fluorescence (XRF) and electron microprobe analysis, with all samples matching the Lake Naivasha Basin source-groups some $400 \mathrm{~km}$ to the north (work in progress; see also Prendergast et al. [2013]). This source group was preferentially exploited by SPN groups in southern Kenya (Merrick and Brown 1984). Obsidian appears only in the form of microlithic elements, bladelet fragments, and heavily curated 


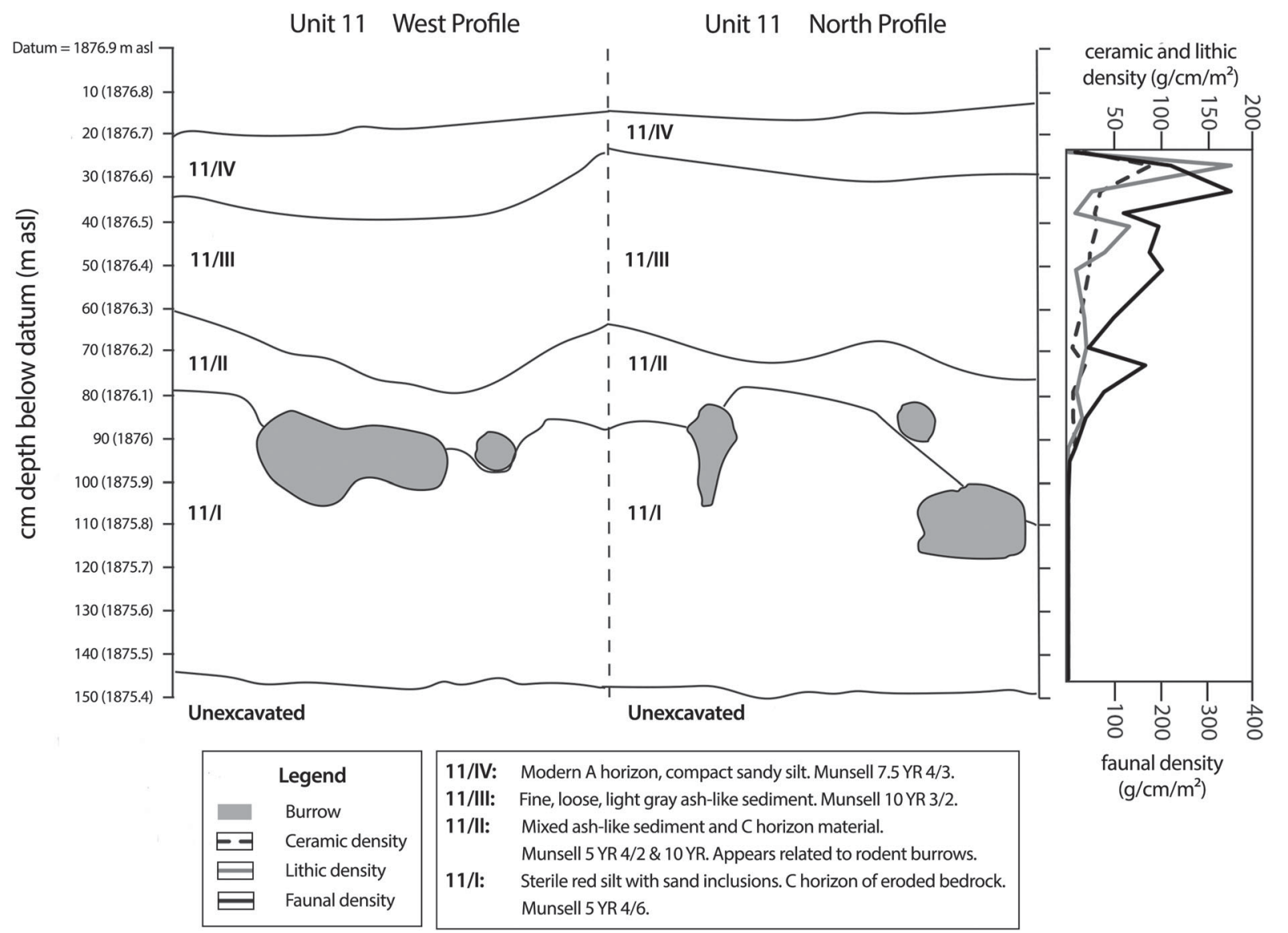

Figure 9. Unit 11 north and west profiles, with Unit 11 artifact densities by depth.

bipolar cores and bipolar flakes, suggesting that inhabitants of Luxmanda were receiving only small bladelets and finished tools rather than larger cores.

Differences in raw material composition and the small size of the Luxmanda assemblage impede detailed comparisons with other SPN sites, but a few preliminary observations are possible. Nearly all of the 80 cores recovered reflect expedient or bipolar flake production. Only five cores (6.25\%) appear to have prepared morphologies, and all of these are chert and were used for the uni- or bi-directional removal of bladelets. Tools are overwhelmingly (85.6\%) made from chert rather than quartz, primarily on flake blanks. As at most other LSA sites, backed pieces form the dominant tool class, and only small numbers of scrapers, borers, burins, notches, and informal tools are present (SUPPLEMENTAL MATERIAL 5). There is also a high frequency of outils écaillés. Microlithic crescent size is known to strongly correlate with PN culture group affiliations (Ambrose 2002; Goldstein and Shaffer 2017). It is therefore interesting to note that while the obsidian crescents cluster strongly with the size ranges from Narosura, Maua Farm, and other SPN sites, the locally produced chert crescents are much smaller $(\overline{\mathrm{x}}=18 \mathrm{~mm})$, and that difference is statistically significant at a $95 \%$ confidence interval (Mann-Whitney $U: 713, z=-5.4, p<.05$ ) (sUPPLEMENTAL MATERIAL 8). Chert crescents have a nearly identical size distribution to those from LSA assemblages at Mumba Rockshelter in the Eyasi Basin and Nasera Rockshelter in the Serengeti plains (Mehlman 1989).

While the SPN is itself a highly variable entity, few of the general characteristics of SPN lithic technology noted in southern Kenya (e.g., abraded platforms, large microliths, bi-directional blade cores, wide endscrapers) are evident at
Luxmanda. However, Luxmanda does share some features with LSA industries documented in the Eyasi Basin and Serengeti plains, including a preference for small convex scrapers, and a high proportion of bipolar pieces (Mehlman 1989: 431). At the same time, the Luxmanda assemblage has a narrow range of formal tool types, compared to these LSA assemblages, and completely lacks the large and wide backed pieces that define hunter-gatherer industries like the Oldeani in the Eyasi-Serengeti area (Mehlman 1989). Taken as a whole, preliminary analysis suggests that the Luxmanda assemblage reflects a locally developed technology. A lack of raw material diversity suggests people were not encountering the higher quality stone sources off the Mbulu Plateau, and may indicate strategies that emphasized lower rates of mobility (Binford 1979; Parry and Kelly 1987). Larger samples and comparison with additional LSA and PN assemblages would be needed to understand the degree to which this unique lithic assemblage results from specialized economic patterns at Luxmanda, and/or from possible relationships between its inhabitants and other SPN groups or local huntergatherers.

\section{Groundstone Technology}

The only in situ groundstone artifacts found at Luxmanda are two polished pebbles from Unit 2 (FIGURE 4A), comparable to some of the smaller "pestle-rubbers" from Narosura (Odner 1972: 58-59). Their function is unknown, but according to local potters, these objects are similar to pebbles used for smoothing and burnishing pottery today. Stone bowl fragments $(n=2)$ (FIGURE 4C), and possible groundstone axes 
A

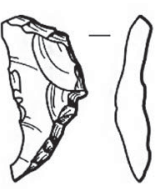

B

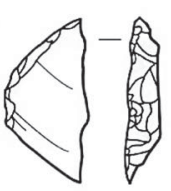

C

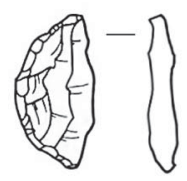

D

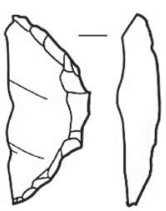

E

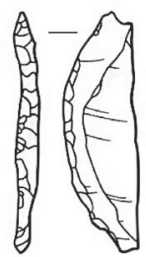

F

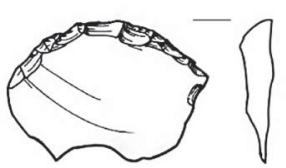

G

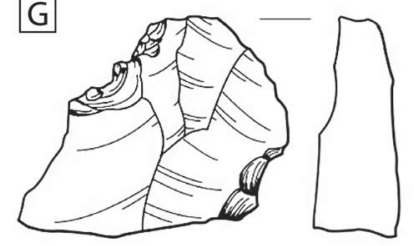

$\mathrm{H}$

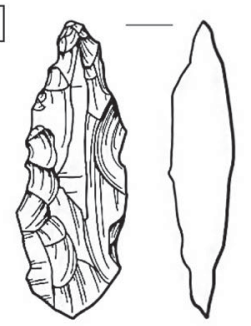

I

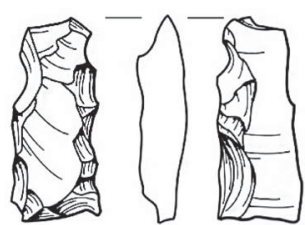

L

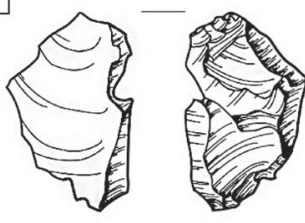

0

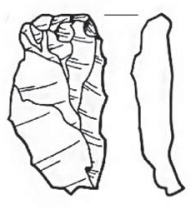

M

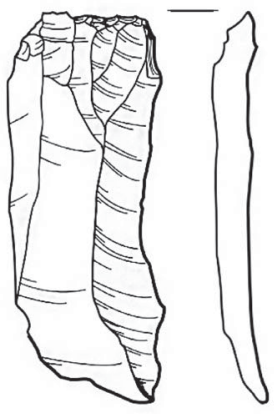

$\mathrm{N}$

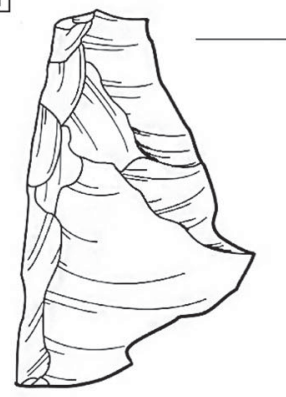

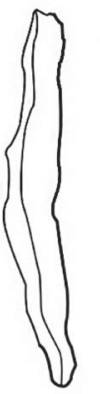

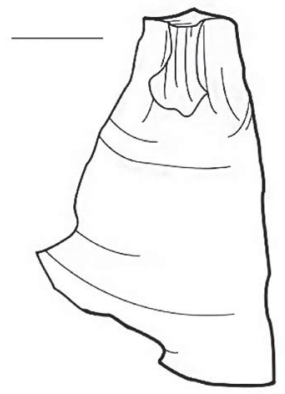

Q
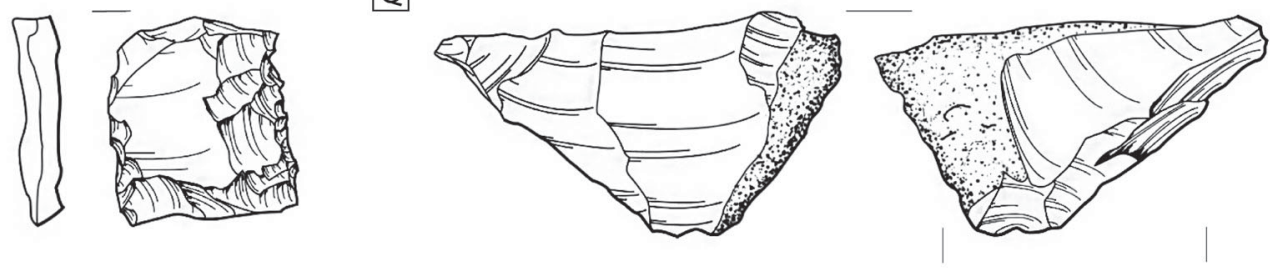

$\mathrm{R}$
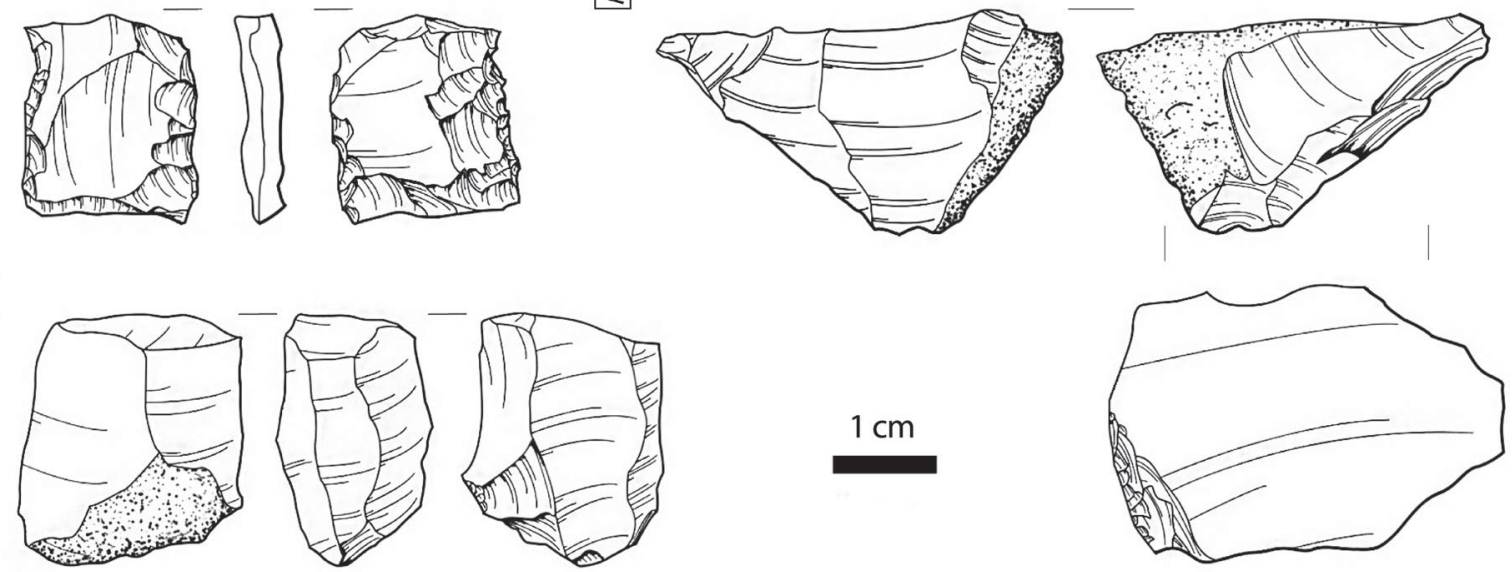

Figure 10. Lithic artifacts from Luxmanda; $\mathrm{A}-\mathrm{E}$ ) microlithic geometrics (crescents); $\mathrm{F}$ ) endscraper; $\mathrm{G}$ ) retouched flake; $\mathrm{H}$ ) borer; I) partially backed bladelet with inverse retouch; J) bec/awl; K) splintered piece; L) bipolar flake; M) blade; N,O) flakes, P) bipolar core; Q, R) bladelet cores. All pieces are chert except for $\mathrm{H}$ (quartz) and E, $\mathrm{K}$ (obsidian).

$(\mathrm{n}=4)$ (FIGURE 4B), two of which are complete and resemble Leakey's (1943) Type C "bossed or knobbed axes," were uncommon but found widely dispersed across the site's surface. Brown (1990) has questioned whether the groundstone axes found at PN sites might have been horn-shapers, similar to the groundstone hammers used by Pokot and other pastoralist groups in eastern Africa to smash cattle skulls for reshaping their horns. Robertshaw and Collett (1983: 72) have argued that such artifacts might have been agricultural hoes. Stone bowls are frequently found at PN sites (Merrick 1973) and are more commonly found at SPN habitations than Elmenteitan habitations. The function that stone bowls served at Luxmanda is unknown.

\section{Ceramic Technology}

A total of 5390 ceramic sherds were recovered during excavations at Luxmanda (Figure 11) (supplemental Material 9). 
The assemblage is wholly recognizable as "Narosura" SPN pottery; bowl-shaped vessels typically have comb-stamped decoration arranged in single bands below rims. Indeed, nearly the full range of decorative motifs seen at Luxmanda is seen at the Narosura type-site as well; those motifs (as described by Odner [1972]) include oblique comb-stamping, comb-stamping combined with zigzag reserved bands, and incised bands with hatching. Also seen at Luxmanda are examples of fine stamping in swagged motifs (Odner 1972: 67, fig. 25d).

As reported by Prendergast et al. (2013), the assemblage is relatively uniform in terms of manufacture, forms, and overall style. A coiling technique was used to shape most if not all vessels. Sherds are relatively well-fired with non-oxidized black cores, as well as some blackening of interior and exterior surfaces. Inclusions include moderate to well-sorted quartzose sand; no other distinctive paste types were identified macroscopically, but a petrographic and/or elemental study of ceramic manufacture and circulation amongst SPN communities could be enlightening. According to local potters, the nearest clay source is near Darwedick, ca. $20 \mathrm{~km}$ from Luxmanda.

Ceramics found in Units 1 and 2 were more intact than those found in any other excavation area, with multiple rim sherds often identifiable per vessel, and larger parts of vessels excavated in situ. This suggests that cultural deposits in Units
A

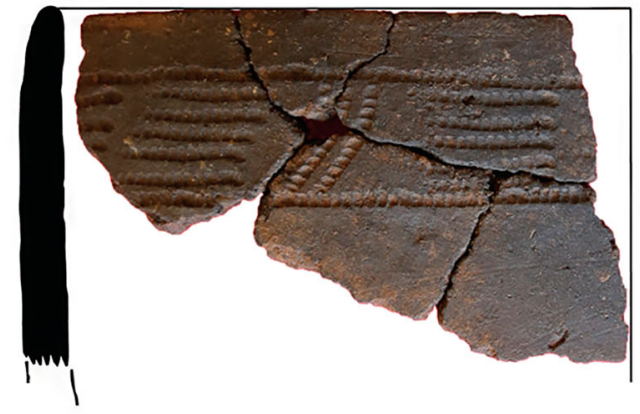

B

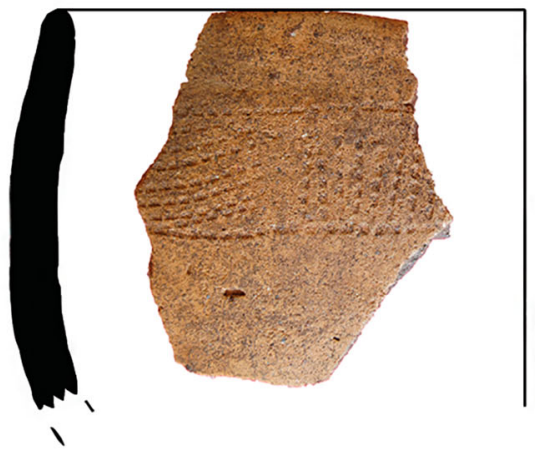

C
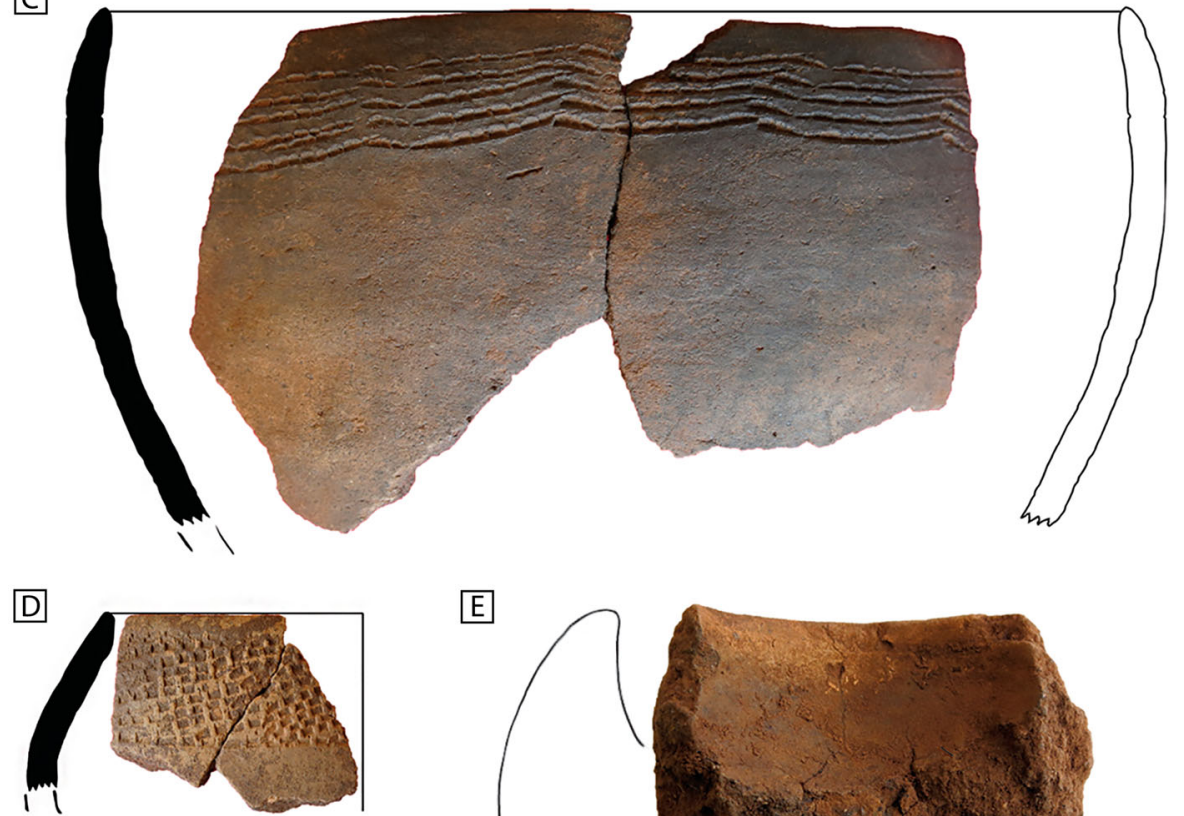

E

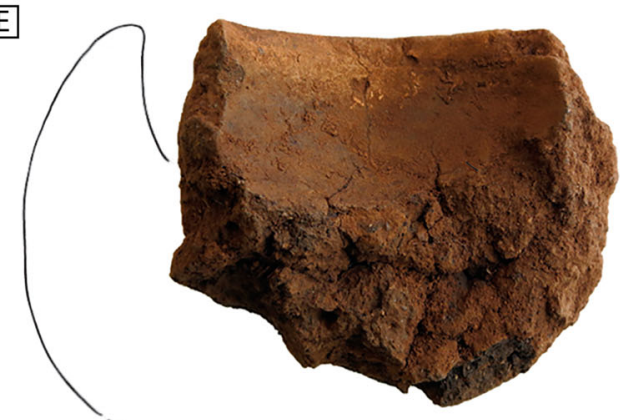

F

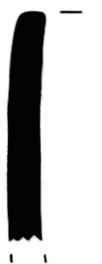

G

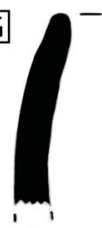

$\mathrm{H}$

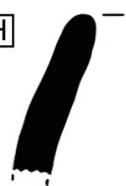

1

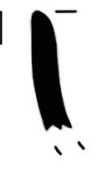

J

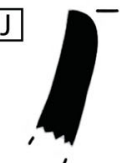

Figure 11. Ceramics from Luxmanda. A-D) stamped decorative motifs; F-J) all rim profiles for other Unit 1 vessels with measurable rim diameters; E) ceramic vessel shaped like a stone bowl. 
1 and 2 are at least marginally less fragmented and dispersed than at other parts of the site. Fifty-four individual vessels were identified from 183 rims found in Units 1 and 2; only one of those vessels (represented by a single rim sherd) appears to be non-"Narosura" and possibly of more recent date. All vessels are bowls, most slightly closed-mouth and relatively consistent in shape but of various sizes. The average rim diameter of measurable vessels in this sample $(n=18)$ is $18 \mathrm{~cm}$, with diameters ranging from 12 to $37 \mathrm{~cm}$ across the mouth opening. Vessel forms and the blackening of surfaces suggest use as multipurpose cooking/serving pots.

Several unusual ceramic surface finds most likely date to the PN as well, including a single clay bead. The only other clay bead recorded from a PN site was recovered in a burial context at Ngorongoro Crater (Gramly 1975). Unique to the Luxmanda assemblage is a globular ceramic vessel with an extremely thick base, a shape suggestive of PN stone bowls. Its function and significance to the people of Luxmanda are unknown.

\section{Faunal Remains}

The Luxmanda faunal assemblage is large $(83 \mathrm{~kg})$, and a sampling strategy was employed whereby about one-fifth of the assemblage (by weight) was examined, including all bone and tooth specimens from contexts deemed high- or medium-priority, and all teeth (at minimum) from lowpriority contexts. A total of 6954 NISP (number of identified specimens) were recorded; $46 \%$ of these are teeth or tooth fragments, since these were prioritized for all contexts. Bone surface preservation is excellent: where recorded, $92 \%$ of the NISP have more than two-thirds of their cortex visible. However, termites and roots are major sources of damage, causing marks on or erasure of surfaces; these effects were so ubiquitous that their frequencies were not consistently recorded. Cut marks and burning were each noted on $8 \%$ of the bone NISP (i.e., the NISP excluding teeth $[\mathrm{n}=3789]$ ). Bones were broken while fresh: $97 \%$ of recorded limb bone fracture planes $(n=1294)$ exhibited green breaks. Cancellous portions-especially limb ends-are grossly underrepresented. Carnivore and rodent tooth marks are rare (each being present on $1 \%$ of the bone NISP). These observations are consistent with a scenario, typical of household production, in which bones are boiled for soup; similar patterns have been documented in other early pastoralist assemblages (Gifford et al. 1980; Marshall 1990).

The assemblage is dominated by domestic caprines $(50 \%$ of a subset of 1436 NISP identifiable to taxon) and cattle ( $44 \%$ of the same subset) (SUPPLEMENTAL MATERIAL 10). Wild fauna are rare $(<1 \%$ for each taxon), and include hare (Lagomorpha), dik-dik (Madoqua sp.), duiker (Cephalophini), hartebeest or topi (Alcelaphus buselaphus or Damaliscus lunatus), warthog (Phacochoerus africanus), and bushpig (Potamochoerus larvatus). There are also equid remains (2\%). Based on dental morphology and postcranial measurements, nearly all are thought to be donkey rather than zebra (Equus quagga). The probable occurrence of donkey at Luxmandato be confirmed via biomolecular techniques-is remarkable as donkeys are rarely identified at PN sites, the only exceptions being Narosura, and possibly two Eyasi Basin sites, though the latter are postdepositionally disturbed (GiffordGonzalez and Kimengich 1984; Prendergast and Mutundu 2009). Their archaeological rarity may reflect attitudes of prehistoric pastoralists toward donkeys, inferred from ethnographic records that describe them not being eaten and being allowed to roam freely, rather than signaling donkeys' unimportance to early pastoralist life (Marshall 2007).

\section{Bone and Ostrich Eggshell Technology}

A small $(n=14)$ but typologically rich assemblage of osseous and ostrich eggshell (OES) artifacts was recovered from Luxmanda (FIGURE 12), and has been published in detail elsewhere (Langley et al. 2017). These items fall into two broad categories: ornamentation and pointed bone. Pieces of ornamentation were identified through comparison with similarly aged items recovered from throughout sub-Saharan Africa, along with the identification of manufacturing traces and use wear. In addition to two complete OES disc beads, two shaped and polished specimens-one of bone, the other of ivory-were identified as originating from pieces of body adornment. Study of the morphology, size, and use wear of the pointed bone artifacts suggests that three of them were probably projectile point tips, two are likely matting needles, and five are minimally altered bone splinters, likely utilized for various domestic tasks. The probable projectile points and matting needles from Luxmanda were made using methods and techniques recorded from earlier periods (i.e., grinding against a coarse-grained grindstone). While worked bone artifacts are rarely reported from PN-era sites, it is notable that the Narosura site produced points ("needles") and altered bone splinters ("awls") like those identified at Luxmanda (Odner 1972).

\section{Chronology}

Samples of charcoal $(n=4)$, ceramics $(n=2)$, tooth apatite $(n=$ $3)$, tooth dentin collagen $(n=1)$, and bone collagen $(n=1)$ were dated via the AMS radiocarbon method at the Illinois State Geological Survey (FIGURE 13, TABLE 1). One of the charcoal samples was obtained from the hearth in Unit 9, another from an ashy area in the Unit 9 midden deposits, and a third came from an ashy feature along the east profile in Unit 10. An additional sample was taken from a relatively deep deposit in Unit 8 that contained a notable cluster of animal bone. The bone collagen sample comes from the human infant found in Unit 10. The tooth samples come from cattle and caprine remains found in the midden deposits of Units 1 and 2 .

With the exception of the four tooth dates, all calibrated dates cluster in the range ca. 3000-2900 CAL B.P. There is good correspondence between the charcoal and bone collagen dates and those obtained on OM in ceramics (see Prendergast et al. [2014] for methods). In particular, we note that the date of the human infant (2925 \pm 20 B.P., $3141-2890$ CAL B.P.) corresponds closely with the charcoal dates from hearth contexts that overlie it by ca. $35 \mathrm{~cm}$. This suggests that although the skeleton appeared to be well separated from the cultural deposits by sterile subsoil, its burial must have occurred during the main occupation of Luxmanda, and not long before the activities of hearth creation and artifact deposition.

However, the four livestock tooth dates from Units 1 and 2 are not only centuries later than the charcoal, bone collagen, and ceramic dates, but are also inverted with respect to stratigraphy. One possibility is that the midden deposits in Units 1 and 2 are later than the midden deposits in Units 8, 9, and 10 , and that furthermore, Units 1 and 2 represent the 

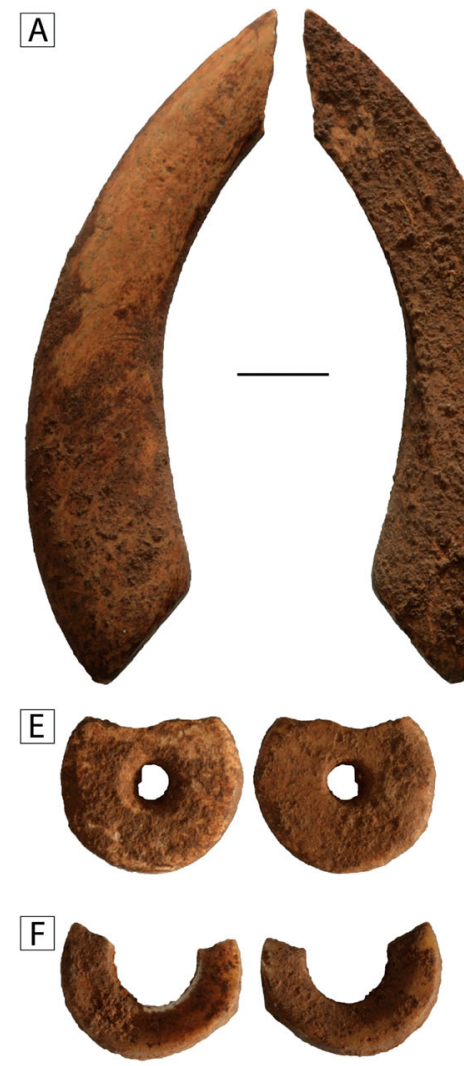

B

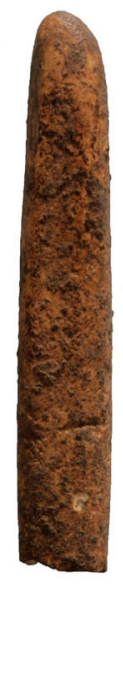

G

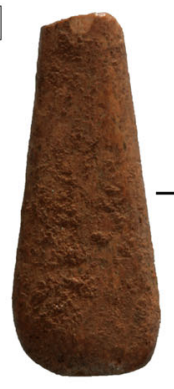

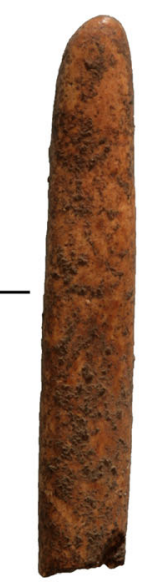

C
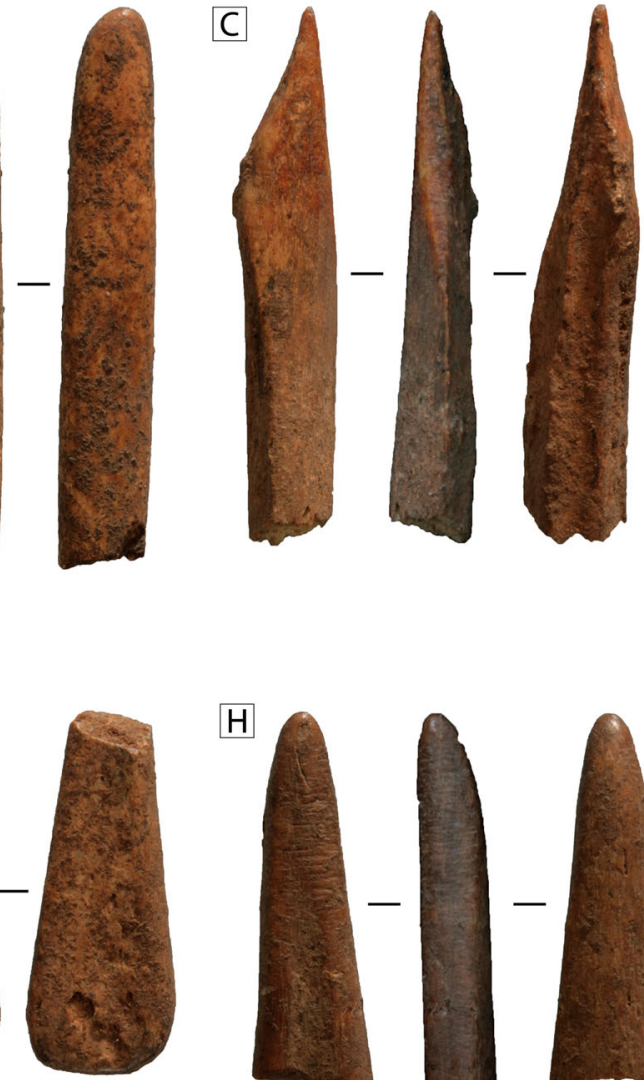

D
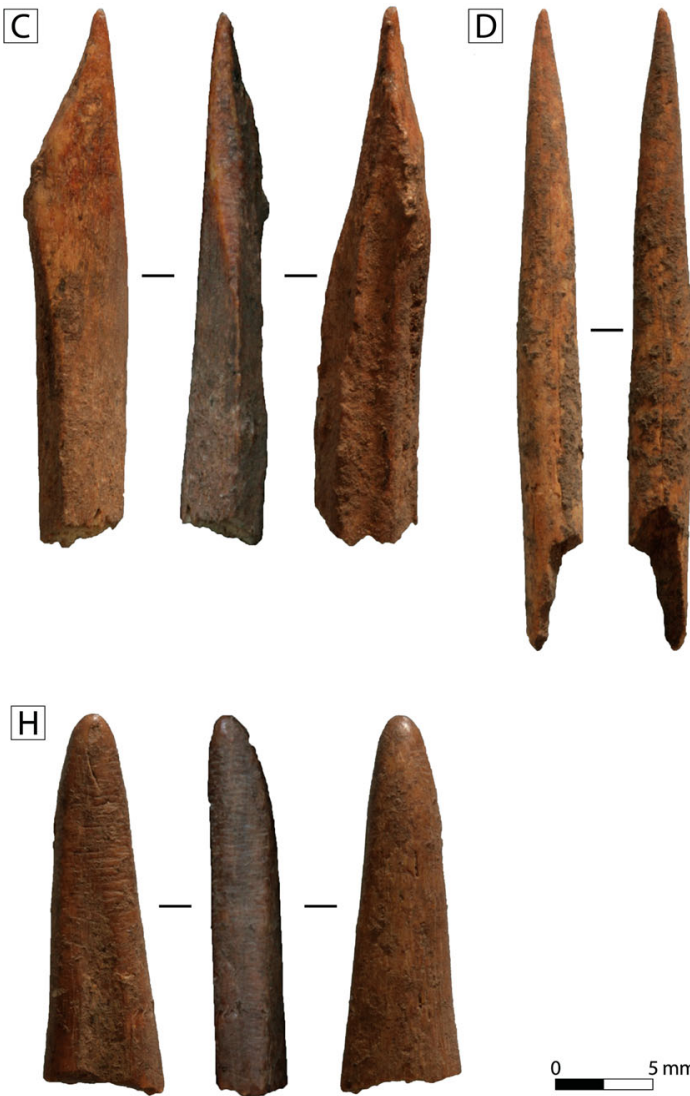

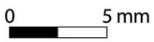

Figure 12. Osseous and ostrich eggshell artifacts from Luxmanda. A) ivory ornament; $\mathrm{B}, \mathrm{H}$ ) terrestrial bone matting needles; C) utilized terrestrial bone splinter; D) probable bone projectile point; E,F) ostrich eggshell beads; and G) tear-drop shaped ornament fragment in terrestrial bone.

postdepositional mixing of materials from distinct mid-late third millennium B.P. occupational episodes. Another possibility is that the midden deposits in all units are roughly contemporaneous, and that either the teeth in Units 1 and 2 are intrusive, or their dates are erroneous. Approximate contemporaneity of midden deposits across the site seems most likely. The date on ceramic OM from the Unit 2 midden is nearly identical to the multiple charcoal dates obtained from midden deposits in Units 8, 9, and 10. The slopes and depths of the midden deposits in Units 1 and 2 suggest they are related to one another. If the midden in Unit 1 is roughly contemporaneous with Unit 2, the dates for midden deposits in Units 8, 9, and 10 suggest contemporaneity sitewide. We therefore suggest that the tooth apatite dates at Luxmanda may be erroneous, as diagenesis can lead to burial environment contamination of both tooth collagen and, especially, apatite (H. Wang, personal communication, 2017).

When compared against dates from other SPN sites, the Luxmanda dates stand out for their tightly defined ranges and-in the cases of charcoal, bone collagen, and ceramic samples-their early chronology (FIGURE 13). As previously discussed by Collett and Robertshaw (1983), the entire PN chronology is problematic for numerous reasons. First, from contexts reported to be associated with "Narosura" pottery (SUPPLEMENTAL MATERIAL 11), there are very few dates overall $(\mathrm{n}=38)$, not counting the additional 11 presented in this paper; of that subset of 38 dates, nearly one-third ( $\mathrm{n}=$ 12) are on apatite and thus are more vulnerable to contamination. Second, most of these dates were obtained in the 1970s-1980s through conventional radiocarbon methods, which often lead to measurement uncertainties of at least \pm 100 years. Recently obtained AMS dates from Luxmanda,
Gileodabeshta 2, and Kahinju (Prendergast et al. 2014; Wright 2005) demonstrate that site-specific chronologies for the PN can now be more tightly defined. We advocate efforts to re-date existing collections (and obtain dates for undated sites). Until then, it will remain difficult to understand Luxmanda's relative place in the overall chronology for the spread of pastoralism through eastern Africa. For now, radiocarbon dates for charcoal and ceramics at Luxmanda are among the earliest for all SPN sites, despite Luxmanda's southernmost location. If this remains true, we must reevaluate the speed with which herders spread southward. We posit, based on the new evidence from Luxmanda, that herders moved much more rapidly from the north than previously acknowledged, as environmental settings were changing in favor of overall wetter-and markedly more unpredictable-conditions throughout the Rift Valley into northern Tanzania ca. 3000 B.P. (Marshall et al. 2011).

\section{Discussion}

Although Luxmanda may appear isolated on maps of SPN sites, there is nothing in the archaeological record to suggest that its occupants were cut off from other herding communities, nor that they were struggling to manage risk along a frontier. Strong similarities in terms of ceramics, groundstone artifacts, and bone technology with "Narosura" sites, such as Crescent Island (Onyango-Abuje 1977) and other Central Rift Valley sites, the Eyasi basin sites (Mehlman 1989; Prendergast 2011), and especially the type-site of Narosura (Odner 1972), suggest links among these communities. The argument for such links is further underscored by Luxmanda's ties to the same obsidian sources used by other SPN 


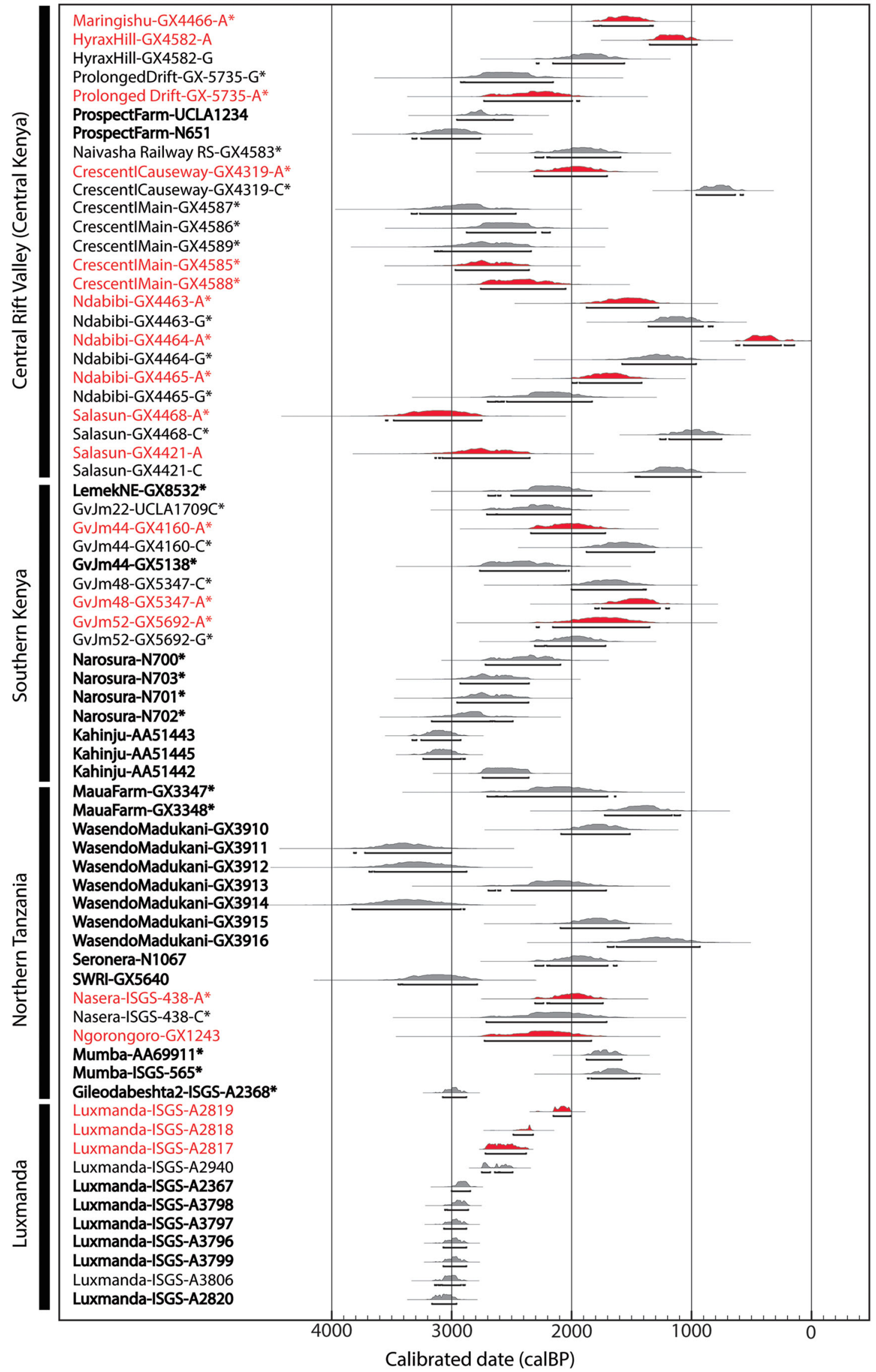

Figure 13. Calibrated radiocarbon dates from Luxmanda and other SPN sites, ordered from north to south. All dates calibrated using the SHCal13 curve (Hogg et al. 2013) in Oxcal 4.3 (Bronk Ramsey 2009), 95.4\% confidence interval. Asterisk (*) indicates that the sample is from a site with pottery identified as "Narosura." Where sites span multiple eras, only samples reported as associated with PN contexts are shown. Charcoal dates are indicated by bold font, while apatite dates are indicated in red. See Supplemental Material 11 for details. 
herders, however peripheral these ties may be. Luxmanda's lithics do exhibit distinctive local patterns, including some similarities with LSA forager assemblages reported elsewhere in northern Tanzania. It is not clear if these similarities reflect contact or convergence. Despite the large number of forageroccupied rockshelters nearby - at least one of which was occupied, minimally, in the millennia prior to and after the occupation of Luxmanda (Prendergast et al. 2013) - there is no obvious evidence for forager-herder interaction at Luxmanda. The faunal assemblage indicates that the occupants were not struggling to sustain their herds, but rather they maintained a specialized livestock-based diet. Small numbers of wild fauna in the Luxmanda assemblage could represent exchanges, or they may represent occasional hunts by pastoralists. Further exploration and additional dating of neighboring shelters may shed light on the existence and nature of patterns of interaction with foragers.

Survey for additional SPN sites in the area will also be essential, and future paleoecological research could help reconstruct the late Holocene pre-agricultural environment. For now, we note that Luxmanda's location on a high, cold, windswept plateau does not seem to fit the pattern of Central Rift Valley SPN sites, which are typically located in highland savanna settings but either on open plains or in protected basins. Luxmanda could theoretically have been part of a local settlement system that included the lacustrine basins, such as Babati and Balangida, below the escarpment; today, Lake Balangida is an essential salt source for Barabaig and Iraqw herders, and livestock movements along the steep grade between the escarpment and the lake are common. However, Janzen (2015) presents stable isotope analyses that indicate SPN pastoralists in Kenya practiced very little seasonal vertical mobility (quite unlike modern herders). Future isotopic analyses of Luxmanda material may shed more specific light on mobility patterns and herd management practices in this region.

Finally, we hope that future research at Luxmanda will reveal the ways in which activity and refuse disposal areas were structured in space and time at the site. Excavations have thus far revealed multiple midden deposits-some apparently roughly contemporaneous-as well as several features: a thick, ashy-appearing deposit interpreted as dung in Units 5 and 11-14; and a hearth overlying an infant burial in Units 9-10, interpreted as possibly being a residential area. In both cases, these features intersected in plan with clusters of magnetic anomalies indicative of occupation, which were detected through geophysical survey. Expansion of this technique may reveal additional activity areas and, together with traditional excavation and micromorphological analyses, may help decipher the structure of the refuse deposits. Ongoing analyses of bulk sediment and micromorphological samples will likewise clarify the site's depositional and occupational history. Middens at SPN sites are generally treated as undifferentiated deposits whose meaning lies in the material culture and fauna present, rather than in the structure of the dump itself. Refuse disposal is, however, highly structured and informative of social behavior in both ethnographic and archaeological case studies (Gifford-Gonzalez 2014).

Excavations at pastoralist sites must be expanded beyond traditional test trenches if archaeologists are to understand SPN sites and the overall SPN phenomenon. The Luxmanda excavations represent a modest step toward this goal. The combination of auger and magnetic surveys with targeted excavations demonstrates these methods' potential for detecting spatial differentiation within pastoralist sites, a promising development for strategic excavation planning, for efficient and extensive data collection, and for tackling the complexities of PN-era sites.

\section{Conclusions}

As the largest intact PN habitation site yet found in eastern Africa, Luxmanda provides an uncommon opportunity to study the lives of specialized herders. This site in north-central Tanzania is also well south of the previously known extent of stone-using pastoralists in eastern Africa, a fact that challenges existing models for the tempo and nature of the spread of herding. In particular, the radiocarbon dates on charcoal and ceramic from Luxmanda cluster at ca. 3000-2900 CAL B.P., placing Luxmanda amongst the earliest of all published SPN sites. This result seems to imply a very rapid spread of food production into the grasslands of southern Kenya and northern Tanzania during a time of marked environmental change. Such a model hinges, however, on the reliability and resolution of dates from other SPN sites. Many of the SPN sites of the Central Rift Valley and southern Kenya should be re-dated, using the AMS method on other materials than bone apatite. This would produce a much more precise chronology for the region, and would enable the types of modeling commonly used in analyses of the spread of food production (Manning et al. 2011; Ozainne et al. 2014). Such analyses could ultimately contribute to ongoing debates about the timing and nature of the arrivals of herders and their livestock in southern Africa as well (Horsburgh et al. 2016; Jerardino et al. 2014; Robinson and Rowan 2017; Sadr 2015; Smith 2008).

\section{Acknowledgments}

Permission to excavate was granted by the Tanzania Commission for Science and Technology [COSTECH 2013-196-NA-2012-50, 2015119-ER-2012-50] and the Department of Antiquities. Export permits were granted by the Department of Antiquities. We are indebted to the people of Luxmanda, in particular, the Gidna family and the welcoming staff of Ufana Secondary School. We thank N. Lasway, R. King'ory, S. Pingu, A. Mkeni, C. Emmanuel, M. Magnani, and the field school students of the University of Dar es Salaam and the University of Wisconsin - La Crosse, without whom our fieldwork would not have been possible. Finally, we gratefully acknowledge the input of two anonymous reviewers, whose comments improved this paper.

\section{Disclosure Statement}

No potential conflict of interest was reported by the authors.

\section{Funding}

Fieldwork in 2013 was supported by grants to MEP by the National Geographic Society (9059-12) and to MEP and AZPM by the Wenner-Gren Foundation (ICRG-111). Fieldwork in 2015 was by supported by a Faculty Research Grant to KMG and by the College of Liberal Studies at the University of Wisconsin - La Crosse. We gratefully acknowledge the Harvard University Center for Geographic Analysis for funding the acquisition of licensed satellite imagery. MEP was supported by a Wenner-Gren Foundation Hunt Postdoctoral Fellowship and by the Radcliffe Institute for Advanced Study, Harvard University, while writing this paper. 


\section{Notes on Contributors}

Katherine M. Grillo (Ph.D. 2012, Washington University in St. Louis) is an Assistant Professor in the Department of Archaeology and Anthropology, University of Wisconsin - La Crosse.

Mary E. Prendergast (Ph.D. 2008, Harvard University) is a Professor at Saint Louis University in Madrid, Spain, and was a Fellow at the Radcliffe Institute for Advanced Study while writing this paper.

Daniel A. Contreras (Ph.D. 2007, Stanford University) is a visiting scientist with the Institut Méditerranéen de Biodiversité et d'Ecologie marine et continentale (IMBE), Aix-Marseille Université, France.

Tom Fitton (Ph.D. 2017, University of York) is an Associate Lecturer in the Department of Archaeology at the University of York.

Agness O. Gidna (Ph.D. 2016, Universidad de Alcalá de Henares) is Head of Paleontology at the National Museum of Tanzania, Dar es Salaam.

Steven T. Goldstein (Ph.D. 2017, Washington University in St. Louis) is a postdoctoral researcher at the Max Planck Institute for the Science of Human History, Jena, Germany.

Matthew C. Knisley (MA 2010, University of Chicago) is a Ph.D. candidate in the Department of Anthropology, University of Chicago.

Michelle C. Langley (Ph.D. 2013, University of Oxford) is a DECRA fellow at the Australian Research Centre for Human Evolution, Environmental Futures Research Institute, at Griffith University in Brisbane, Australia.

Audax Z. P. Mabulla (Ph.D. 1996, University of Florida) is the Director General of the National Museums of Tanzania.

\section{References}

Ambrose, S. H. 1998. "Chronology of the Later Stone Age and Food Production in East Africa." Journal of Archaeological Science 25: 377-392.

Ambrose, S. H. 2001. "East African Neolithic." In Encyclopedia of Prehistory. Volume 1: Africa, edited by P. N. Peregrine and M. Ember, 97-109. New York: Kluwer Academic.

Ambrose, S. H. 2002. "Small Things Remembered: Origins of Early Microlithic Industries in Sub-Saharan Africa.” In Thinking Small: Global Perspectives on Microlithization, edited by R. G. Elston, S. L. Kuhn, and S. Ambrose, 9-29. Arlington, VA: American Anthropological Association.

Ambrose, S. H., and N. E. Sikes. 1991. "Soil Carbon Isotope Evidence for Holocene Habitat Change in the Kenya Rift Valley." Science 253 (5026): 1402-1405.

Barthelme, J. 1985. Fisher-Hunters and Neolithic Pastoralists in East Turkana, Kenya. BAR International Series 254. Oxford: B.A.R

Biagetti, S. 2014. Ethnoarchaeology of the Kel Tadrart Tuareg. Pastoralism and Resilience in Central Sahara. New York: Springer.

Binford, L. R. 1979. "Organization and Formation Processes: Looking at Curated Technologies." Journal of Anthropological Research 35 (3): 255-273.

Boles, O. J. C., and P. J. Lane. 2016. “The Green, Green Grass of Home: An Archaeo-Ecological Approach to Pastoralist Settlement in Central Kenya." Azania: Archaeological Research in Africa 51 (4): 507-530.

Börjeson, L. 2004. "The History of Iraqw Intensive Agriculture, Tanzania." In Islands of Intensive Agriculture in Eastern Africa: Past \& Present, edited by M. Widgren and J. E. G. Sutton, 68-104. Oxford: James Currey Ltd.

Bower, J., C. M. Nelson, A. F. Waibel, and S. Wandibba. 1977. “The University of Massachusetts' Later Stone Age/Pastoral Neolithic Comparative Study in Central Kenya: An Overview." Azania: Archaeological Research in Africa 12: 119-146.

Bronk Ramsey, C. 2009. "Bayesian Analysis of Radiocarbon Dates." Radiocarbon 51 (1): 337-360.

Brown, J. 1990. "Horn-shaping Ground-stone Axe-hammers." Azania: Archaeological Research in Africa 25 (1): 57-67.

Carrer, F. 2015. "Herding Strategies, Dairy Economy and Seasonal Sites in the Southern Alps: Ethnoarchaeological Inferences and Archaeological Implications." Journal of Mediterranean Archaeology 28 (1): 3-22.
Collett, D., and P. Robertshaw. 1983. "Problems in the Interpretation of Radiocarbon Dates: The Pastoral Neolithic of East Africa." African Archaeological Review 1: 57-74.

Dunne, J., R. P. Evershed, M. Salque, L. Cramp, S. Bruni, K. Ryan, S. Biagetti, and S. di Lernia. 2012. "First Dairying in Green Saharan Africa in the Fifth Millennium BC." Nature 486 (7403): 390-394.

Gifford, D., G. Isaac, and C. M. Nelson. 1980. "Evidence for Predation and Pastoralism at Prolonged Drift: A Pastoral Neolithic Site in Kenya." Azania: Archaeological Research in Africa 15: 57-108.

Gifford-Gonzalez, D. 1998a. "Gender and Early Pastoralists in East Africa." In Gender in African Prehistory, edited by S. Kent, 115137. Walnut Creek: Altamira.

Gifford-Gonzalez, D. 1998b. "Early Pastoralists in East Africa: Ecological and Social Dimensions." Journal of Anthropological Archaeology 17: 166-200.

Gifford-Gonzalez, D. 2000. "Animal Disease Challenges to the Emergence of Pastoralism in Sub-Saharan Africa." African Archaeological Review 17 (3): 95-139.

Gifford-Gonzalez, D. 2014. "Constructing Community Through Refuse Disposal.” African Archaeological Review 31 (2): 339-382.

Gifford-Gonzalez, D., and J. Kimengich. 1984. "Faunal Evidence for Early Stock-keeping in the Central Rift of Kenya: Preliminary Evidence." In Origin and Early Development of Food-producing Cultures in North-Eastern Africa, edited by L. Krzyzaniak and M. Kobusiewicz, 457-471. Poznan: Archaeological Museum of Poznan.

Goldstein, S. T., and J. M. Munyiri. 2017. "The Elmenteitan Obsidian Quarry (GsJj50): New Perspectives on Obsidian Access and Exchange During the Pastoral Neolithic in Southern Kenya." African Archaeological Review 34 (1): 43-73.

Goldstein, S. T., and C. M. Shaffer. 2017. "Experimental and Archaeological Investigations of Backed Microlith Function Among Mid-to-late Holocene Herders in Southwestern Kenya." Archaeological and Anthropological Sciences 9 (8): 1767-1788.

Gramly, R. M. 1975. "Pastoralists and Hunters: Recent Prehistory in Southern Kenya and Northern Tanzania." Ph.D. diss., Harvard University.

Grillo, K. M. 2012. "The Materiality of Mobile Pastoralism: Ethnoarchaeological Perspectives from Samburu, Kenya." Ph.D. diss., Washington University in St. Louis.

Grillo, K. M., and E. A. Hildebrand. 2013. "The Context of Early Megalithic Architecture in Eastern Africa: The Turkana Basin c. 5000-4000 BP.” Azania: Archaeological Research in Africa 48 (2): 193-217.

Hogg, A., Q. Hua, P. G. Blackwell, M. Niu, C. E. Buck, T. P. Guilderson, T. J. Heaton, J. Palmer, P. J. Reimer, R. W. Reimer, C. S. M. Turney, and S. R. H. Zimmerman. 2013. "SHCal13 Southern Hemisphere calibration, 0-50,000 Years cal BP.” Radiocarbon 55 (4): 1889-1903.

Honeychurch, W., and C. A. Makarewicz. 2016. "The Archaeology of Pastoral Nomadism." Annual Review of Anthropology 45 (1): 341-359.

Horsburgh, K. A., J. Orton, and R. G. Klein. 2016. "Beware the Springbok in Sheep's Clothing: How Secure are the Faunal Identifications upon which we Build our Models?" African Archaeological Review 33 (4): 353-361.

Janzen, A. 2015. "Mobility and Herd Management Strategies of Early Pastoralists in South-Central Kenya, 3000-1200 BP.” Ph.D. diss., University of California - Santa Cruz.

Jerardino, A., J. Fort, N. Isern, and B. Rondelli. 2014. "Cultural Diffusion was the Main Driving Mechanism of the Neolithic Transition in Southern Africa." PLOS ONE 9 (12): e113672.

Lane, P. J. 2004. "The 'Moving Frontier' and the Transition to Food Production in Kenya." Azania: Archaeological Research in Africa 39: 243-264.

Lane, P. 2013. "Trajectories of Pastoralism in Northern and Central Kenya: An Overview of the Archaeological and Environmental Evidence." In Pastoralism in Africa: Past, Present and Future, edited by M. Bollig, M. Schnegg, and H. P. Wotzka, 104-144. New York: Berghahn Books.

Lane, P. J. 2016. "Entangled Banks and the Domestication of East African Pastoral Landscapes.” In Archaeology of Entanglement, edited by L. Der and F. Fernandini, 127-150. Walnut Creek, CA: Left Coast Press.

Langley, M. C., M. E. Prendergast, and K. M. Grillo. 2017. “Organic Technology in the Pastoral Neolithic: Osseous and Eggshell Artefacts from Luxmanda, Tanzania." Archaeological and Anthropological Sciences. doi:10.1007/s12520-017-0528-z. 
Leakey, M. D. 1943. "Notes on the Ground and Polished Stone Axes of East Africa." Journal of the East Africa and Uganda Natural History Society 17: 182-195.

Mabulla, A. Z. P., and A. O. Gidna. 2015. "El amanecer de la creatividad humana: el arte rupestre del área centro-norte de Tanzania/The Dawn of Human Imagination: The Rock Art of North-central Tanzania." In La Cuna de la Humanidad/The Cradle of Humankind, edited by M. Domínguez-Rodrigo and E. Baquedano, 99-120/266-271. Alcalá de Henares: Museo Arqueológico Regional.

Makarewicz, C. A. 2013. "A Pastoralist Manifesto: Breaking Stereotypes and Re-conceptualizing Pastoralism in the Near Eastern Neolithic." Levant 45 (2): 159-174.

Manning, K., R. Pelling, T. Higham, J. L. Schwenniger, and D. Q. Fuller. 2011. "4500-Year Old Domesticated Pearl Millet (Pennisetum glaucum) from the Tilemsi Valley, Mali: New Insights into an Alternative Cereal Domestication Pathway." Journal of Archaeological Science 38 (2): 312-322.

Marshall, F. 1990. "Origins of Specialized Pastoral Production in East Africa." American Anthropologist 92: 873-894.

Marshall, F. 2007. "African Pastoral Perspectives on Domestication of the Donkey: A First Synthesis.” In Rethinking Agriculture: Archaeological and Ethnoarchaeological Perspectives, edited by J. Iriarte and L. Vrydaghs, 371-407. Walnut Creek, CA: Left Coast Press.

Marshall, F., K. M. Grillo, and K. Arco. 2011. "Prehistoric Pastoralists and Social Responses to Climatic Risk in East Africa." In Sustainable Lifeways: Cultural Persistence in an Ever-changing Environment, edited by N. Miller, K. Moore and K. Ryan, 38-73. Philadelphia: University of Pennsylvania Museum of Archaeology and Anthropology.

Marshall, F., and E. A. Hildebrand. 2002. "Cattle before Crops: The Beginnings of Food Production in Africa." Journal of World Prehistory 16 (2): 99-143.

Mbae, B. N. 1990. "The Ethnoarchaeolgoy of Maasai Settlements and Refuse Disposal Patterns in the Lemek Area." In Early Pastoralists of South-Western Kenya, edited by P. Robertshaw, 279-282. Nairobi: British Institute in East Africa.

Mehlman, M. J. 1989. "Later Quaternary Archaeological Sequences in Northern Tanzania.” Ph.D. diss., University of Illinois at UrbanaChampaign.

Merrick, H. 1973. "Aspects of the Size and Shape Variation of the East African Stone Bowls.” Azania: Archaeological Research in Africa 8 (1): 115-130.

Merrick, H., and F. H. Brown. 1984. "Obsidian Sources and Patterns of Source Utilization in Kenya and Northern Tanzania: Some Initial Findings." African Archaeological Review 2: 129-152.

Mjema, E. 2008. "The Later Stone Age of Endadu Rock Shelter, Babati District, Northern Tanzania.” Masters thesis, University of Dar es Salaam.

Muchiru, A. N., D. Western, and R. S. Reid. 2009. "The Impact of Abandoned Pastoral Settlements on Plant and Nutrient Succession in an African Savanna Ecosystem." Journal of Arid Environments 73 (3): 322-331.

Odner, K. 1972. "Excavations at Narosura, a Stone Bowl Site in the Southern Kenya Highlands." Azania: Archaeological Research in Africa 7 (1): 25-92.

Onyango-Abuje, J. C. 1977. "A Contribution to the Study of the Neolithic in East Africa with Particular Reference to NakuruNaivasha Basins." Ph.D. diss., University of California, Berkeley.

Ozainne, S., L. Lespez, A. Garnier, A. Ballouche, K. Neumann, O. Pays, and E. Huysecom. 2014. "A Question of Timing: Spatio-temporal Structure and Mechanisms of Early Agriculture Expansion in West Africa." Journal of Archaeological Science 50: 359-368.

Parry, W. J., and K. L. Kelly. 1987. "Expedient Core Technology and Sedentism.” In The Organization of Core Technology, edited by J. K. Johnson and C. M. Murrow, 285-304. Boulder: Westview Press.

Porter, A. 2012. Mobile Pastoralism and the Formation of Near Eastern Civilizations: Weaving Together Society. Cambridge: Cambridge University Press.

Prendergast, M. E. 2011. "Hunters and Herders at the Periphery: The Spread of Herding in Eastern Africa." In People and Animals in
Holocene Africa: Recent Advances in Archaeozoology, edited by $\mathrm{H}$. Jousse and J. Lesur, 43-58. Frankfurt: Africa Magna Verlag.

Prendergast, M. E., K. M. Grillo, A. Z. P. Mabulla, and H. Wang. 2014 "New Dates for Kansyore and Pastoral Neolithic Ceramics in the Eyasi Basin, Tanzania." Journal of African Archaeology 12 (1): 89-98. Prendergast, M. E., A. Z. P. Mabulla, K. M. Grillo, L. G. Broderick, O Seitsonen, A. O. Gidna, and D. Gifford-Gonzalez. 2013. "Pastoral Neolithic Sites on the Southern Mbulu Plateau, Tanzania." Azania: Archaeological Research in Africa 48 (4): 498-520.

Prendergast, M. E., and K. K. Mutundu. 2009. "Late Holocene Zooarchaeology in East Africa: Ethnographic Analogues and Interpretive Challenges." Documenta Archaeobiologiae 7: 203-232.

Robbins, L. H. 1973. "Turkana Material Culture Viewed from an Archaeological Perspective.” World Archaeology 5 (2): 209-214.

Robertshaw, P. 1990. Early Pastoralists of South-Western Kenya. Nairobi: British Institute in Eastern Africa.

Robertshaw, P., and D. Collett. 1983. "The Identification of Pastoral Peoples in the Archaeological Record: An Example from East Africa." World Archaeology 15 (1): 67-78.

Robertshaw, P., and F. Marshall. 1990. "Ngamuriak." In Early Pastoralists of South-western Kenya, edited by P. Robertshaw, 5472. Memoirs of the British Institute in Eastern Africa 11. Nairobi: British Institute in Eastern Africa.

Robinson, J. R., and J. Rowan. 2017. "Holocene Paleoenvironmental Change in Southeastern Africa (Makwe Rockshelter, Zambia) Implications for the Spread of Pastoralism." Quaternary Science Reviews 156: 57-68.

Sadr, K. 2015. "Livestock First Reached Southern Africa in Two Separate Events.” PLOS ONE 10 (8): e0134215.

Shahack-Gross, R. 2011. "Herbivorous Livestock Dung: Formation, Taphonomy, Methods for Identification, and Archaeological Significance." Journal of Archaeological Science 38: 205-218.

Shahack-Gross, R., A. Simons, and S. H. Ambrose. 2008. "Identification of Pastoral Sites Using Stable Nitrogen and Carbon Isotopes from Bulk Sediment Samples: A Case Study in Modern and Archaeological Pastoral Settlements in Kenya." Journal of Archaeological Science 35 (4): 983-990.

Smith, A. B. 2008. "Is Absence of Evidence, Evidence of Absence? Problems in the Archaeology of Early Herding Societies of Southern Africa." In The Archaeology of Mobility: Old World and New World Nomadism, edited by H. Bernard and W. Wendrich, 264-279. Los Angeles: Cotsen Institute of Archaeology, University of California, Los Angeles.

Spencer, P. 1973. Nomads in Alliance. Symbiosis and Growth Among the Rendille and Samburu of Kenya. London: Oxford University Press.

Straight, B. S. 2006. "Becoming Dead: The Entangled Agencies of the Dearly Departed." Anthropology and Humanism 31 (2): 101-110.

Thompson, L. G., E. Mosley-Thompson, M. E. Davis, K. A. Henderson, H. H. Brecher, V. S. Zagorodnov, T. A. Mashiotta, P. N. Lin, V. N. Mikhalenko, D. R. Hardy, and J. Beer. 2002. "Kilimanjaro Ice Core Records: Evidence of Holocene Climate Change in Tropical Africa." Science 298 (5593): 589-593.

United Republic of Tanzania. 2012. "National Sample Census of Agriculture 2007/2008. Regional Report: Manyara Region.” Report on file with the Ministry of Agriculture, United Republic of Tanzania. https://harvestchoice.org/publications/tanzania-national-samplecensus-agriculture-20072008-small-holder-agriculture-regional-.

Weissbrod, L. 2011. "The Small Animals of Maasai Settlement: Ethnoarchaeological Investigations of the Commensalism Model." Ph.D. diss., Washington University in St. Louis.

Wright, D. K. 2005. "New Perspectives on Early Regional Interaction Networks of East African Trade: A View from Tsavo National Park, Kenya." African Archaeological Review 22 (3): 111140.

Wright, J. 2016. "Households Without Houses: Mobility and Moorings on the Eurasian Steppe." Journal of Anthropological Research 72 (2): 133-157.

Zeder, M. A. 2011. "The Origins of Agriculture in the Near East." Current Anthropology 52 (S4): S221-S235. 